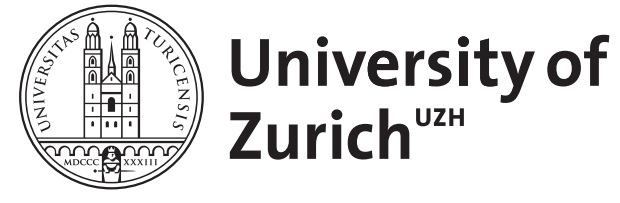

\title{
Gold(I) Catalysts with Bifunctional P, N Ligands
}

\author{
Wetzel, C ; Kunz, P C ; Thiel, I ; Spingler, B
}

\begin{abstract}
A series of phosphanes with imidazolyl substituents were prepared as hemilabile PN ligands. The corresponding gold(I) complexes were tested as bifunctional catalysts in the Markovnikov hydration of 1-octyne, as well as in the synthesis of propargylamines by the three component coupling reaction of piperidine, benzaldehyde, and phenylacetylene. While the activity in the hydration of 1-octyne was low, the complexes are potent catalysts for the three component coupling reaction. In homogeneous solution the conversions to the respective propargylamine were considerably higher than under aqueous biphasic conditions. The connectivity of the imidazolyl substituents to the phosphorus atom, their substitution pattern, as well as the number of heteroaromatic substituents have pronounced effects on the catalytic activity of the corresponding gold(I) complexes. Furthermore, formation of polymetallic species with $\mathrm{Au}(2), \mathrm{Au}(3)$, and $\mathrm{Au}(4)$ units has been observed and the solid-state structures of the compounds (5) (2) $\mathrm{Au}(3) \mathrm{Cl}(2)] \mathrm{Cl}$ and $(3 \mathrm{c})(2) \mathrm{Au}(4) \mathrm{Cl}(2)] \mathrm{Cl}(2)$ (3c = tris (2-isopropylimidazol-4(5)-yl phosphane, $5=$ 2-tert-butylimidazol-4(5)-yldiphenyl phosphane) were determined. The gold(I) complexes of imidazol-2yl phosphane ligands proved to be a novel source for bis(NHC)gold(I) complexes (NHC = N-heterocyclic carbene).
\end{abstract}

DOI: https://doi.org/10.1021/ic2011259

Posted at the Zurich Open Repository and Archive, University of Zurich

ZORA URL: https://doi.org/10.5167/uzh-59542

Journal Article

Accepted Version

Originally published at:

Wetzel, C; Kunz, P C; Thiel, I; Spingler, B (2011). Gold(I) Catalysts with Bifunctional P, N Ligands. Inorganic Chemistry, 50(16):7863-7870.

DOI: https://doi.org/10.1021/ic2011259 


\title{
Gold(I) catalysts with bifunctional P,N ligands
}

\author{
Corinna Wetzel, ${ }^{[a]}$ Peter C. Kunz, ${ }^{[a]}$ Indre Thiel, ${ }^{[a]}$ Bernhard Spingler ${ }^{[b]}$
}

[a] Institut für Anorganische Chemie und Strukturchemie I, Heinrich-Heine Universität Düsseldorf, Universitätsstr. 1, D-40225 Düsseldorf, Germany. Fax: (+)49 211 8112287; E-mail:

peter.kunz@uni-duesseldorf.de.

[b] Institute of Inorganic Chemistry, University Zurich-Irchel, Winterthurerstr. 190, CH-8057

Zürich, Switzerland.

\begin{abstract}
A series of phosphanes with imidazolyl substituents were prepared as hemilabile PN ligands. The corresponding gold(I) complexes were tested as bifunctional catalysts in the Markovnikov hydration of 1-octyne as well as in the synthesis of propargylamines by the three component coupling reaction of piperidine, benzaldehyde and phenylacetylene. While the activity in the hydration of 1-octyne was low, the complexes are potent catalysts for the three component coupling reaction. In homogenous solution the conversions to the respective propargylamine were considerably higher than under aqueous biphasic conditions. The connectivity of the imidazolyl substituents to the phosphorous atom, their substitution pattern as well as the number of heteroaromatic substituents have pronounced effects on the catalytic activity of the corresponding gold(I) complexes. Furthermore, formation of polymetallic species with $\mathrm{Au}_{2}, \mathrm{Au}_{3}$ and $\mathrm{Au}_{4}$ units has been observed and the solid-state structures of the compounds $\left[(\mathbf{5})_{2} \mathrm{Au}_{3} \mathrm{Cl}_{2}\right] \mathrm{Cl}$ and $\left[(\mathbf{3 c})_{2} \mathrm{Au}_{4} \mathrm{Cl}_{2}\right] \mathrm{Cl}_{2}$ $\mathbf{3 c}=$ tris(2-isopropylimidazol-4(5)-yl phosphane, $\mathbf{5}=$ 2-tert-butylimidazol-4(5)-yldiphenyl phosphane) were determined. The gold(I) complexes of imidazol-2-yl phosphane ligands proved to be a novel source for bis(NHC)gold(I) complexes ( $\mathrm{NHC}=N$-heterocyclic carbene).
\end{abstract}

Keywords: Carbene Complexes $\bullet$ Catalysis $\bullet$ Coupling Reactions $\bullet$ Gold $\bullet$ PN Ligands

\section{Introduction}


For a long time, gold has been regarded as inactive as a catalytic metal due to its "chemical inertness". However, recent work on the high catalytic activity of gold compounds in heterogeneous and homogenous catalysis proved the opposite. ${ }^{1}$ Gold catalyzed $\mathrm{C}-\mathrm{C}$ coupling reactions provide excellent methods for the construction of complex molecules under mild conditions. ${ }^{2}$ First, salt like gold compounds as $\mathrm{AuCl}_{3}$ or $\mathrm{HAuCl}_{4}$ were used as catalysts followed by gold complexes bearing phosphane ligands. ${ }^{3}$

Pyridylphosphanes are well-established PN ligands in transition metal chemistry. ${ }^{4}$ Imidazolebased phosphane ligands are, however, less studied. The soft phosphorus and harder nitrogen atoms of those ligands make them potentially hemilabile ${ }^{5}$ and bifunctional. ${ }^{6}$ A variety of reactions including $\mathrm{C}-\mathrm{C}$ bond formation ${ }^{7}$, carbonylation of amines $^{8}$, asymmetric aldol reactions ${ }^{9}$ and hydration of terminal alkynes ${ }^{10}$ have been reported using gold(I) catalysts with bifunctional PN ligands. An interesting reaction is the $\mathrm{C}-\mathrm{C}$ bond formation in the multicomponent coupling reaction of an aldehyde, amine and alkyne to the respective propargylamine. One-pot multicomponent coupling reactions are efficient methods for the preparation of complex molecules starting from readily available materials.

The synthesis of propargylamines has attracted considerable attention over the last few years due to their pharmaceutical relevance and their importance as building blocks in the preparation of nitrogen-containing molecules, and as key intermediates for natural product synthesis. ${ }^{11}$ For these syntheses, besides gold(I) and gold(III) compounds ${ }^{12}$ iron $^{13}$ and indium ${ }^{14}$ salts have been employed as catalysts. ${ }^{12}$ The functionalization of hydrocarbons is another important area for catalytic transformations. Here the hydration of terminal alkynes to the respective ketones (Markovnikov product) or aldehydes (anti-Markovnikov product) is of particular interest. Gold(I) species have started to replace gold(III) complexes ${ }^{15}$, since Teles et al. showed that complexes of the general composition $[(\mathrm{L}) \mathrm{Au}]^{+}$- with L being a phosphane, arsane or phosphite ligand - are very good catalysts for the addition of alcohols to alkynes, if an acid co-catalyst is present. ${ }^{16}$ In the last few years gold(I)-NHC (N-heterocyclic carbene) complexes ${ }^{17}$ have started to gain immense interest and many catalytic active gold(I)-species concerning the hydration of alkynes have been described. ${ }^{18}$ Nonetheless there are several recent examples of gold(I)-phosphane complexes ${ }^{19}$ including gold(I) 
complexes with bifunctional pyridylphosphane ligands, which readily convert 1-pentyne to 2pentanone. $^{20}$

In this work we describe the synthesis and structural properties of novel gold(I) complexes, containing bifunctional imidazolylphosphanes. The new compounds were tested for their application as catalysts in the synthesis of propargylamines and the hydration of terminal alkynes. Based on the results in the catalytic trials, we report different pathways for potential deactivation of the $(\mathrm{L}) \mathrm{AuCl}$ catalysts.

\section{Results and Discussion}

In this work we used different homologous series of polydentate imidazolylphosphanes (Figure 1) and investigated their application as ligands in gold(I) catalyzed reactions.

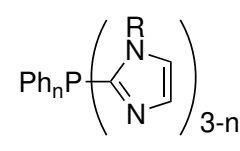

a)

1a-c, 2a-c

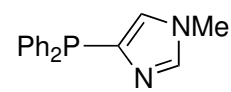

c) 6

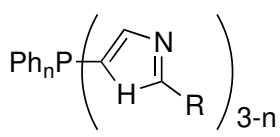

b)

3a-c, 4,5

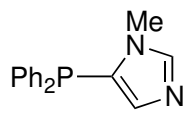

d) 7

Figure 1. PN Ligands used a) imidazol-2-yl phosphanes $\mathrm{R}=\mathrm{H}$ (1), Me (2), b) imidazol-4(5)-yl phosphanes $\mathrm{R}=i \operatorname{Pr}(3), \mathrm{Ph}(4), t \mathrm{Bu}(5)\{\mathrm{n}=2-0$ (a-c) $\}$, and c) 1-methylimidazol-4yldiphenylphosphane (6) and 1-methylimidazol-5-yldiphenylphosphane (7).

In contrast to the well-elaborated procedures for the preparation of imidazol-2-ylphosphanes, syntheses of the isomeric imidazol-4-yl- and imidazol-5-ylphosphanes are only scarcely described. ${ }^{21}$ The imidazol-2-ylphosphanes 1a,c, 2a,c, 3a-c, 6 and 7 were prepared according to literature procedures. ${ }^{22}$ For the imidazol-4(5)-ylphosphane ligands we adopted a protocol previously described by us starting from 2-organylimidazoles (Scheme 1). ${ }^{23}$ The ${ }^{31} \mathrm{P}\left\{{ }^{1} \mathrm{H}\right\}$ NMR spectroscopic data of synthesized ligands is summarized in Table 1 and the ${ }^{31} \mathrm{P}\left\{{ }^{1} \mathrm{H}\right\}$ NMR chemical shifts are typical for mono-, bis- and tris(imidazolyl)phosphanes.

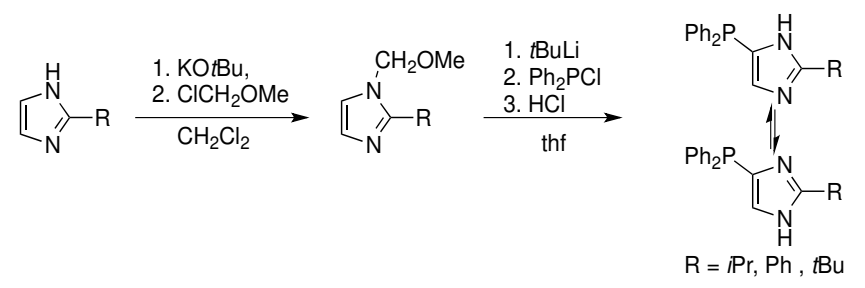


Scheme 1. Reaction schemes for the syntheses of imidazol-4(5)-yl phosphanes 4-MIP $(\mathrm{R}=i \mathrm{Pr}, \mathrm{Ph}$, $t \mathrm{Bu})$.

$$
\mathrm{PR}_{3}+[(\text { tht }) \mathrm{AuCl}] \underset{- \text { tht }}{\longrightarrow}\left(\mathrm{PR}_{3}\right) \mathrm{AuCl}
$$

Scheme 2. Reaction scheme for the synthesis of complexes of the type (L)AuCl.

The gold(I) phosphane complexes of the type [(L)AuCl] $(\mathrm{L}=$ imidazolyl phosphane ligand) are obtained as white solids in good yields by reaction of the corresponding ligand and $[($ tht $) \mathrm{AuCl}]$ in dichloromethane or methanol at room temperature (Scheme 2). The complex [(6)AuCl] was prepared in acetone as both the tris(imidazol-2-yl)phosphane ligands and the corresponding gold(I) complexes tend to decompose in protic solvents. The decomposition of all gold(I) complexes bearing imidazol-2-yl phosphane ligands was monitored by time dependent ${ }^{1} \mathrm{H}$ NMR spectroscopy in methanol- $d_{4}$ and $\mathrm{D}_{2} \mathrm{O}$ (see part catalyst deactivation pathways and ESI). All complexes were characterized by ${ }^{1} \mathrm{H}$ and ${ }^{31} \mathrm{P}\left\{{ }^{1} \mathrm{H}\right\}$ NMR spectroscopy as well as MALDI and ESI mass spectrometry and elemental analysis (see ESI). The ${ }^{31} \mathrm{P}\left\{{ }^{1} \mathrm{H}\right\}$ NMR chemical shifts of the ligands and the resulting complexes (L)AuCl are summarized in Table 1. The ${ }^{31} \mathrm{P}\left\{{ }^{1} \mathrm{H}\right\}$ NMR spectra of the complexes show a substantial coordination shift of 35 to $57 \mathrm{ppm}$ to lower field compared to the free ligands.

Due to the ambidentate nature of the PN ligands, next to the usual linear $(\kappa P)$ coordination pattern of gold, dinuclear $\left(\kappa^{2} P, N\right)$ structures can result. Previously, solid state structures of the mononuclear complex $[(\mathbf{3 a}) \mathrm{AuCl}]$ and the dimeric structure $\left[\{(\mathbf{3 c}) \mathrm{Au}\}_{2}\right] \mathrm{Cl}_{2}$ have been reported by us. ${ }^{24} \mathrm{~A}$ coordination shift of $\Delta \delta\left({ }^{31} \mathrm{P}\right)>50 \mathrm{ppm}$ is usually found for a bridging coordination mode of the PN ligand, whereas a shift of ca. $40 \mathrm{ppm}$ is found in the mononuclear complexes. The MALDI MS spectra of all complexes (L)AuCl show the signal for the ion $[(\mathrm{L}) \mathrm{AuCl}]^{+}$as the basic peak and a further signal for the corresponding dimer $\left[(\mathrm{L})_{2} \mathrm{Au}_{2} \mathrm{Cl}\right]^{+}$.

Table 1. Spectroscopic data of the ligands and gold(I) complexes $\left(\Delta \delta=\delta_{\mathrm{C}}-\delta_{\mathrm{L}}\right)$.

\begin{tabular}{|c|c|c|c|}
\hline Ligand & $\left.\delta_{\mathrm{L}}{ }^{31} \mathrm{P}\right)$ & $\left.\delta_{\mathrm{C}}{ }^{(31} \mathrm{P}\right)$ & $\begin{array}{c}\Delta \delta\left({ }^{31} \mathrm{P}\right. \\
)\end{array}$ \\
\hline 1a & $-22^{\mathrm{b}}$ & $16^{\mathrm{b}}$ & 38 \\
\hline
\end{tabular}




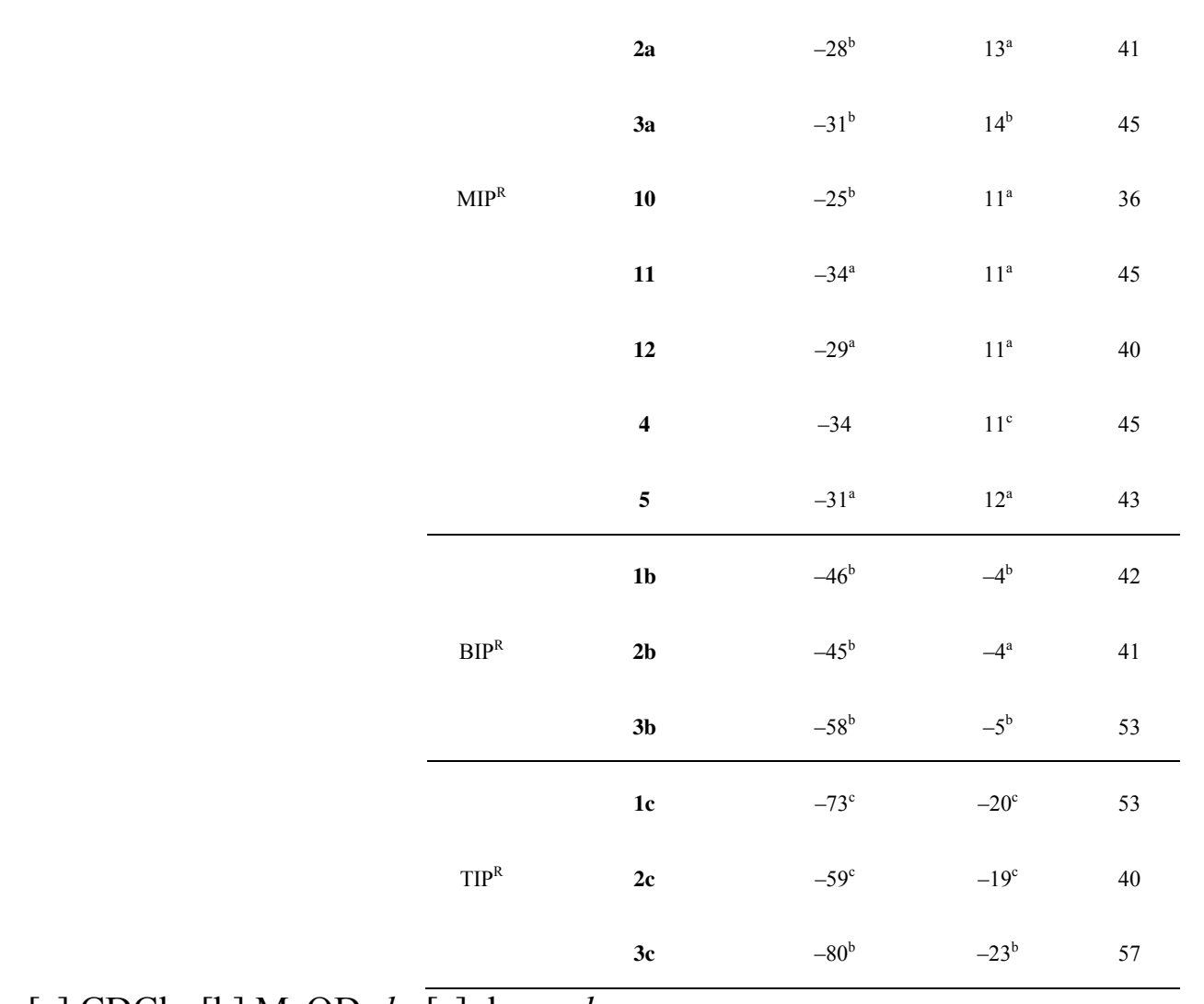

[a] $\mathrm{CDCl}_{3},[\mathrm{~b}] \mathrm{MeOD}-d_{4}, \overline{[\mathrm{c}] \mathrm{dmso}-d_{6}}$

Three component coupling reaction. Selected gold(I) complexes with PN ligands have been investigated as potential bifunctional catalysts in the synthesis of propargylamines by three component coupling of piperidine, benzaldehyde and phenyl acetylene (Scheme 3).

First we investigated the catalytic activity of the selected gold(I) complexes under biphasic conditions, as especially the tris(imidazolyl)phosphane ligands are water-soluble. The catalytic trials were carried out in aqueous reaction mixtures under an atmosphere of $\mathrm{N}_{2}$ at $40{ }^{\circ} \mathrm{C}$ for $42 \mathrm{~h}$ using the procedure published by Elie et al. $^{25}$ The results of the trials under biphasic conditions are summarized in Table 2. Complex (2b)AuCl shows the highest activity with a conversion of $75 \%$ and a catalyst loading of only $0.5 \mathrm{~mol} \%$ but when the catalyst loading was increased to $5 \mathrm{~mol} \%$ even conversion by complex (2c) $\mathrm{AuCl}$ raised from 65 to $97 \%$. It has to be mentioned that the complexes (L) $\mathrm{AuCl}$ of ligands $\mathbf{2 a}, \mathbf{2} \mathbf{b}, \mathbf{3 a}$ and $\mathbf{3} \mathbf{b}$, did not dissolve completely under the conditions used for the biphasic catalysis (at $0.5 \mathrm{~mol} \%$ ).
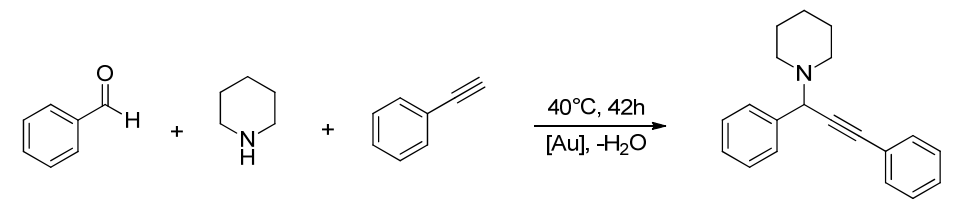
Scheme 3. Three component coupling of benzaldehyde, piperidine and phenylacetylene catalyzed by gold(I) complexes.

Table 2. Catalytic trials of complexes (L)AuCl in the three-component coupling of phenylacetylene, benzaldehyde and piperidine under biphasic conditions (conversion determined by ${ }^{1} \mathrm{H}$ NMR spectroscopy, given in mean \pm error).

\begin{tabular}{cccc}
\hline Entry & Ligand & Catalyst loading $[\mathrm{mol} \%]$ & Conversion [\%] \\
\hline 1 & $2-\operatorname{MIP}^{\mathrm{NMe}}(\mathbf{2 a})$ & 0.5 & $63 \pm 1$ \\
2 & $2-\operatorname{BIP}^{\mathrm{NMe}}(\mathbf{2 b})$ & 0.5 & $75 \pm 5$ \\
3 & $2-\operatorname{TIP}^{\mathrm{NMe}}(\mathbf{2 c})$ & 0.5 & $65 \pm 3$ \\
4 & $2-\operatorname{TIP}^{\mathrm{NMe}}(\mathbf{2 c})$ & 5 & $97 \pm 1$ \\
5 & $4-\mathrm{MIP}^{\mathrm{iPr}}(\mathbf{3 a})$ & 0.5 & $16 \pm 1$ \\
6 & $4-\mathrm{BIP}^{\mathrm{iPr}}(\mathbf{3 b})$ & 0.5 & $40 \pm 2$ \\
7 & $4-\operatorname{TIP}^{i P r}(\mathbf{3 c})$ & 0.5 & $37 \pm 3$ \\
\hline
\end{tabular}

When the gold(I) complexes were used in the neat mixture of the organic reactants the catalytic trials could be carried out under homogenous conditions $\left(40{ }^{\circ} \mathrm{C}, 42 \mathrm{~h}\right)$. The results obtained by the so modified protocol are summarized in Table 3. The conversions are considerably higher compared to the results obtained under aqueous biphasic conditions.

Table 3. Screening of catalysts (L)AuCl in the three components coupling of phenyl acetylene, benzaldehyde and piperidine under homogenous conditions. $\mathrm{Na}$ [(TPPMS)AuCl], $\mathrm{Na}_{2}$ [(TPPDS)AuCl], $\mathrm{Na}_{3}$ [(TPPTS)AuCl] and [( $\left.\left.\mathrm{Ph}_{3} \mathrm{P}\right) \mathrm{AuCl}\right]$ as reference compound (conversion determined by ${ }^{1} \mathrm{H}$ NMR spectroscopy, given in mean \pm error).

\begin{tabular}{cccc}
\hline Entry & Ligand & Catalyst loading [mol \%] & Conversion [\%] \\
\hline 1 & $2-\mathrm{MIP}^{\mathrm{NMe}}(\mathbf{2 a})$ & 0.5 & $70 \pm 2$ \\
2 & $4-\mathrm{MIP}^{\mathrm{NMe}}(\mathbf{6})$ & 0.5 & $61 \pm 3$ \\
3 & $5-\mathrm{MIP}^{\mathrm{NMe}}(\mathbf{7})$ & 0.5 & $92 \pm 1$ \\
4 & $2-\mathrm{BIP}^{\mathrm{NMe}}(\mathbf{2 b})$ & 0.5 & $82 \pm 2$ \\
5 & $2-\mathrm{TIP}^{\mathrm{NMe}}(\mathbf{2 c})$ & 0.5 & $95 \pm 2$ \\
6 & $2-\mathrm{TIP}^{\mathrm{NMe}}(\mathbf{2 c})$ & 5 & $98 \pm 1$ \\
7 & $2-\mathrm{MIP}^{\mathrm{H}}(\mathbf{1 a})$ & 0.5 & $46 \pm 1$ \\
8 & $2-\mathrm{BIP}^{\mathrm{H}}(\mathbf{1 b})$ & 0.5 & $74 \pm 2$
\end{tabular}




\begin{tabular}{cccc}
9 & $2-\mathrm{TIP}^{\mathrm{H}}(\mathbf{1 c})$ & 0.5 & $87 \pm 1$ \\
10 & $4-\mathrm{MIP}^{\mathrm{iPr}}(\mathbf{3 a})$ & 0.5 & $26 \pm 2$ \\
11 & $4-\mathrm{BIP}^{\mathrm{iPr}}(\mathbf{3 b})$ & 0.5 & $35 \pm 4$ \\
12 & $4-\operatorname{TIP}^{\mathrm{iPr}}(\mathbf{3 c})$ & 0.5 & $74 \pm 1$ \\
13 & $4-\mathrm{MIP}^{\mathrm{PBu}}(\mathbf{5})$ & 0.5 & $67 \pm 2$ \\
14 & $\operatorname{TPPMS}_{15}$ & 0.5 & $25 \pm 1$ \\
16 & $\operatorname{TPPDS}_{10}$ & 0.5 & $32 \pm 5$ \\
17 & $\operatorname{TPPTS}_{3}$ & 0.5 & $39 \pm 4$ \\
\hline
\end{tabular}

It is obvious that the connectivity (2-, 4- or 5-yl) as well as the substitution pattern of the imidazolyl substituents in the PN ligands show an effect on the catalytic activity of their gold(I) complexes. The catalytic activity of the complexes increases within every series in the order MIP $<$ BIP $<$ TIP. Within the series, the complexes with the $N$-methylated ligands 2a-c show the highest activity. Complex (2c) AuCl shows the highest conversion of $95 \%$ at a catalyst loading of $0.5 \mathrm{~mol} \%$. Here, the conversion is as high as under biphasic conditions using the tenfold higher catalyst loading.

Within the series of the complexes $(\mathrm{L}) \mathrm{AuCl}$ with the isomeric ligands $2-\mathrm{MIP}^{\mathrm{NMe}}(\mathbf{2 a}), 4-\mathrm{MIP}^{\mathrm{NMe}}$ (6) and 5-MIP ${ }^{\mathrm{NMe}}$ (7) (entries 1-3), (2a) $\mathrm{AuCl}$ and (6) $\mathrm{AuCl}$ exhibit about the same conversion (70 and $61 \%$, respectively), whereas (7)AuCl shows a conversion of $92 \%$. All complexes, with exception of (3a) $\mathrm{AuCl}$ (entry 10), show higher catalytic activity then the reference compounds (entries 14-17).

Markovnikov hydration of terminal alkynes. Since gold(I) complexes with pyridylphosphane ligands have been shown to convert 1-pentyne to 2-pentanone in very high yields, ${ }^{20}$ the catalytic activity of our gold(I) imidazolylphosphane complexes in the hydration of terminal alkynes was investigated as well (Scheme 4). The respective gold(I) complex (5 mol\% in regard to the alkyne) was dissolved in degassed acetone, the chloride abstracted in situ by addition of one equivalent AgOTf. 1-Ocytne and water (10 eq. in regard to the alkyne) were added to the solution, which was then stirred at $60{ }^{\circ} \mathrm{C}$. The results of the catalytic trials are summarized in Table 4 . 


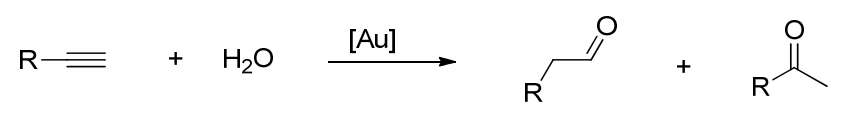

Scheme 4. Markovnikov hydration of alkynes.

Table 4. Preformed gold complexes and their catalytic activity after halide abstraction in situ using AgOTf in acetone.

\begin{tabular}{|c|c|c|}
\hline Entry & Catalyst & Conversion $^{a}[\%(\mathrm{~h})]$ \\
\hline 1 & (1a) $\mathrm{AuCl}$ & $6(22)$ \\
\hline 2 & (2a) $\mathrm{AuCl}$ & $30(22)$ \\
\hline 3 & (2b) $\mathrm{AuCl}$ & $5(22)$ \\
\hline 4 & (2c) $\mathrm{AuCl}$ & $0(22)$ \\
\hline 5 & (6) $\mathrm{AuCl}$ & $17(22)$ \\
\hline 6 & (3a) $\mathrm{AuCl}$ & $2(22)$ \\
\hline 7 & (3b) $\mathrm{AuCl}$ & $0(22)$ \\
\hline 8 & {$\left[\left\{(\mathbf{3 c}) \mathrm{Au}_{2}\right\}_{2}\right] \mathrm{Cl}_{2}$} & $0(22)$ \\
\hline 9 & {$\left[\{(\mathbf{3 c}) \mathrm{Au}\}_{2}\{\mathrm{AuCl}\}_{2}\right] \mathrm{Cl}_{2}$} & $1(22)$ \\
\hline 10 & {$\left[\left\{(\mathbf{5}) \mathrm{Au}_{2}{ }_{2} \mathrm{AuCl}_{2}\right] \mathrm{Cl}\right.$} & $60(22)$ \\
\hline 11 & (4) $\mathrm{AuCl}$ & $61(22), 93(48)$ \\
\hline 12 & {$\left[\left(\mathrm{PPh}_{3}\right) \mathrm{AuCl}\right]$} & $95(22)$ \\
\hline
\end{tabular}

[a] conversion to 2-octanone.

While gold complexes with bis(imidazolyl)phosphanes as well as tris(imidazolyl)phosphanes of any kind proved inactive, complexes with mono(imidazolyl)phosphanes show catalytic activity towards the hydration of 1-octyne. The most active gold(I) imidazolyl complexes are $\left[\{(5) \mathrm{Au}\}_{2} \mathrm{AuCl}_{2}\right] \mathrm{Cl}$ and $[(4) \mathrm{AuCl}]$ with $60 \%$ and $61 \%$ conversion of 1-octyne to 2-octanone within $22 \mathrm{~h}$ respectively. $\mathrm{N}$-Methylated imidazol-2-yl ligands show a higher conversion rate than ligands containing a NH-function and ligands possessing large substituents in the position adjacent to the nitrogen show the highest conversion rates (entries 1-4).

Interestingly, the triphenylphosphane gold(I) complex $\left[\left(\mathrm{PPh}_{3}\right) \mathrm{AuCl}\right]$ shows the highest activity in the conversion of 1-octyne to 2-octanone (entry 12). Complexes of the type $\left[\left(\mathrm{PPh}_{3}\right) \mathrm{Au}\left(\mathrm{CH}_{3}\right)\right]$ have already been shown to be good catalysts in the hydration of alkynes in the presence of acid cocatalysts. The thus generated $\left[\left(\mathrm{PPh}_{3}\right) \mathrm{Au}\right]^{+}$is active in many reactions involving triple bonds, ${ }^{26}$ one of 
them being the addition of methanol across a triple bond. However, $\left[\left(\mathrm{PPh}_{3}\right) \mathrm{AuCl}\right]$ has not been mentioned as catalyst for the hydration of terminal alkynes before.

Catalyst deactivation pathways. A major problem of multifunctional ligands in catalytic applications is the elucidation of the structure of the actually active species. In the case of gold(I) complexes of PN ligands, e.g. imidazolyl phosphanes, it is hard to define which species is the catalytic active species and which species are present in solution. Different coordination modes as $\kappa P$ - or $\kappa N$-monodentate, $\kappa^{2} P N$-chelating, $\mu-P N$ bridging as well as polynuclear species with combination of these binding modes can be formed. Complexes bearing $\mathrm{Au}_{2}, \mathrm{Au}_{3}$ and $\mathrm{Au}_{4}$ units have been observed with different imidazolyl phosphane ligands before. ${ }^{27}$ From the reaction mixture of trial 12, Table 3 , we obtained a crystal of $\left[(\mathbf{5})_{2} \mathrm{Au}_{3} \mathrm{Cl}_{2}\right] \mathrm{Cl}$ whose structure could be determined by X-ray diffraction (Figure 2). Such polynuclear complexes can be prepared directed by reaction of the PN ligands with [(tht)AuCl] in the corresponding stoichiometry (Scheme 5). This has been demonstrated by the formation of complexes $\left[(\mathrm{L})_{2} \mathrm{Au}_{3} \mathrm{Cl}_{2}\right] \mathrm{Cl}(\mathrm{L}=\mathbf{3 c}, \mathbf{5})$ and complex $\left[(3 \mathbf{c})_{2} \mathrm{Au}_{4} \mathrm{Cl}_{2}\right] \mathrm{Cl}_{2}$ (Figure 3). The $\mathrm{Au}_{\mathrm{n}}$ complexes $(\mathrm{n}=2-4)$ of the PN ligands show coordination shifts of $\Delta \delta\left({ }^{31} \mathrm{P}\right)>50 \mathrm{ppm}$ which is typical for a bridging coordination mode of the PN ligand, as stated before. The polynuclear structure of these complexes is seen by the characteristic signals of the molecular ions in the MALDI-TOF spectra.

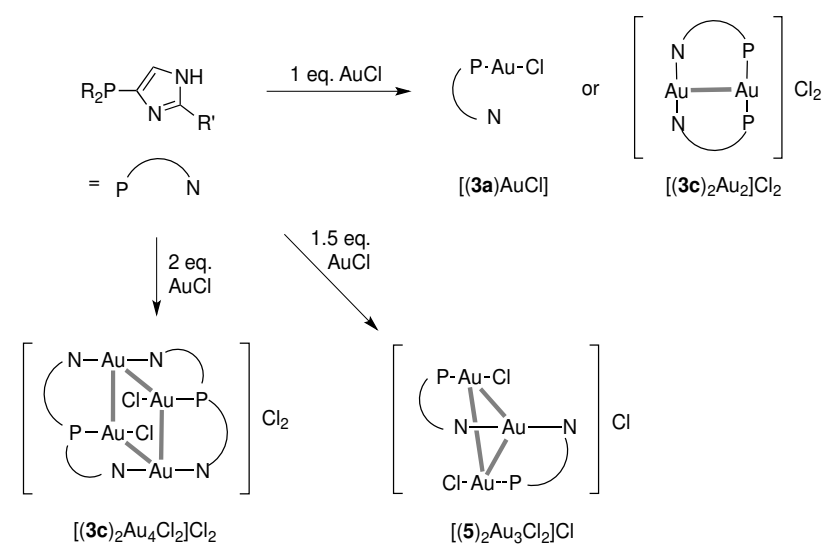

Scheme 5. Synthesis of polynuclear complexes $\mathrm{Au}_{\mathrm{n}}$ stabilized by PN ligands. 


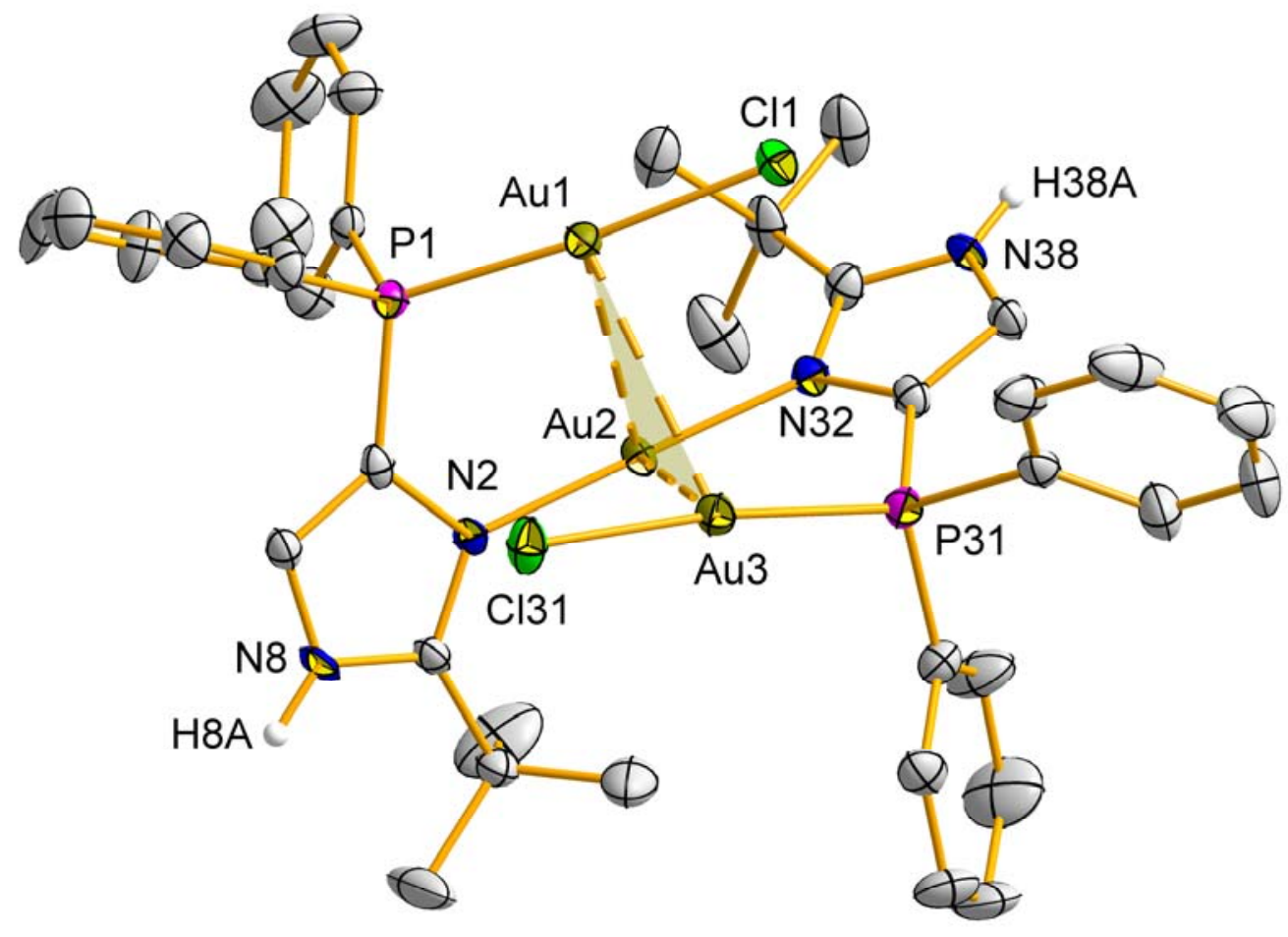

Figure 2. Molecular structure of $\left[(5)_{2} \mathrm{Au}_{3} \mathrm{Cl}_{2}\right] \mathrm{Cl}$, ellipsoids at $30 \%$ probability. Hydrogen atoms, solvent molecules, and non-coordinated chloride anions were omitted for clarity. Selected bond lengths $[\AA]$ and angles $\left[^{\circ}\right]$ :Au1-Au2 3.1863(4), Au1-Au3 3.3075(4), Au2-Au3 3.1043(4), Au2-N2 2.013(5), Au2-N32 2.017(6), Au1-P1 2.236(2), Au1-Cl1 2.290(2), Au3-P31 2.232(2), Au3-Cl31 2.294(2), Au1-Au2-Au3 63.427(9), Au1-Au3-Au2 59.495(9), Au2-Au1-Au3 57.078(9), N2-Au2N32 176.0(2), P1-Au1-C11 175.24(7), P31-Au3-Cl31 173.55(8). 


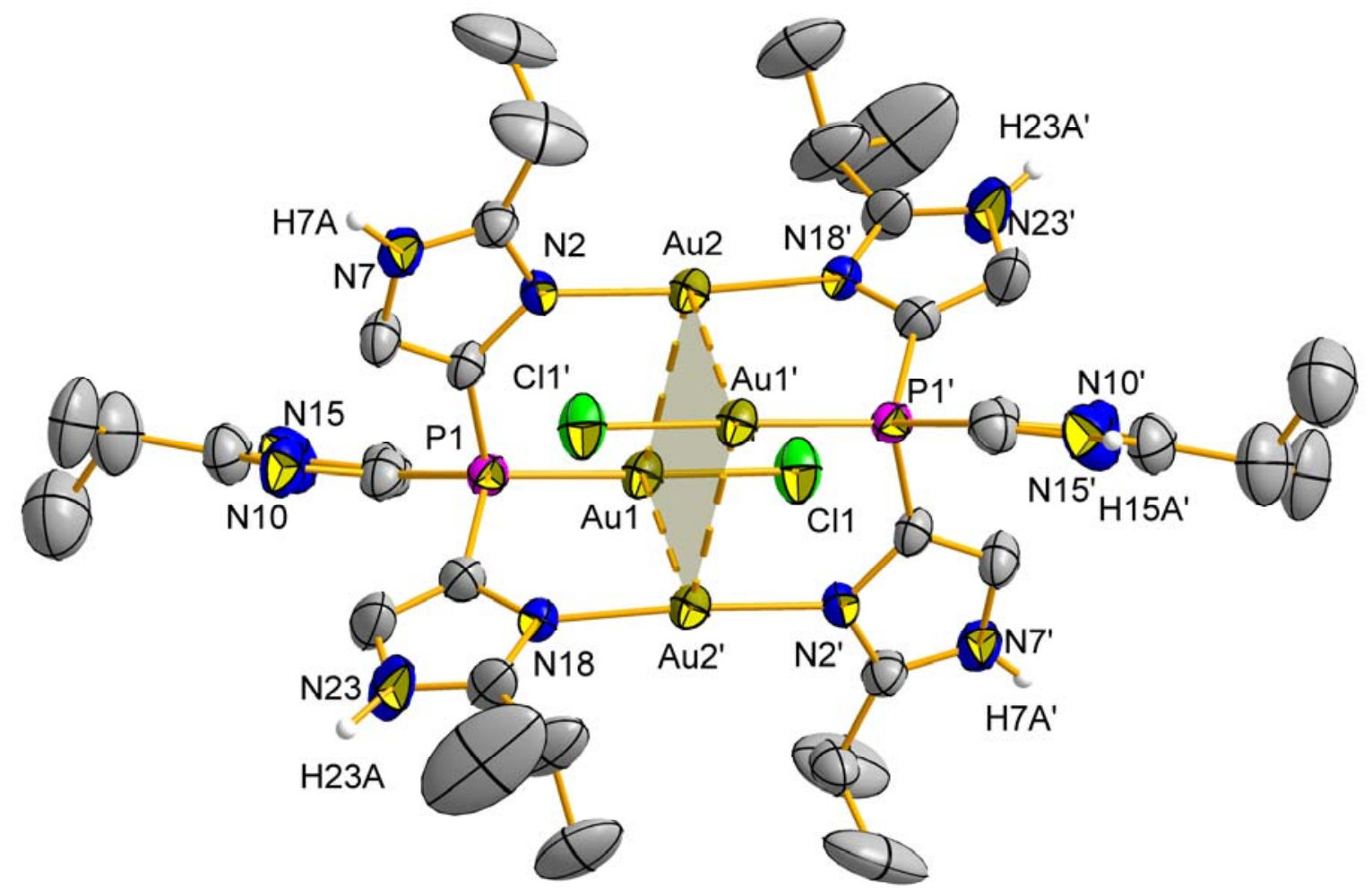

Figure 3. Molecular structure of $\left[(3 \mathbf{c})_{2} \mathrm{Au}_{4} \mathrm{Cl}_{2}\right] \mathrm{Cl}_{2}$, ellipsoids at $30 \%$ probability. Hydrogen atoms and non-coordinated chloride anions were omitted for clarity. Selected bond lengths $[\AA]$ and angles $\left[^{\circ}\right]$ : Au1-Au2 3.0695(4), Au1-Au2\#1 3.1102(4), Au1-P1 2.2258(19), Au1-C11 2.2848(19), Au2N18 2.019(6), Au2-N2 2.023(6), P1-Au1-Cl1 176.73(7), N2-Au2-N18 174.1(2), Au1-Au2-Au1 94.246(10), Au2-Au1-Au2 85.754(10).

Based on the results of the catalytic trials under biphasic conditions and further stability studies, we observed that gold(I) complexes of imidazol-2-ylphosphane ligands are unstable in protic solvents, especially complexes (1c) $\mathrm{AuCl}$ and $(\mathbf{2 c}) \mathrm{AuCl}$. In water and methanol solvolysis of the $\mathrm{P}-\mathrm{C}$ bond and therefore decomposition of the gold complexes yields $\mathrm{H}_{3} \mathrm{PO}_{3}$ and $\mathrm{P}\left(\mathrm{OCH}_{3}\right)_{3}$, respectively, imidazole and the corresponding bis(NHC) gold(I) complexes $\left[\left(\mathrm{C}_{3} \mathrm{H}_{4} \mathrm{~N}_{2}\right)_{2} \mathrm{Au}\right]^{+}$(C6) and $\left[\left(\mathrm{C}_{4} \mathrm{H}_{5} \mathrm{~N}_{2}\right)_{2} \mathrm{Au}\right]^{+}(\mathbf{C 3})$, respectively (Scheme 6).

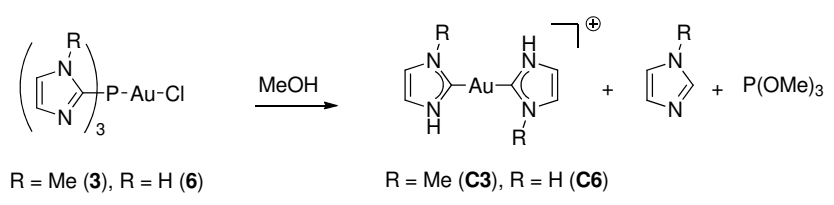

Scheme 6. Formation of gold(I) bis(NHC) complexes. 
The formation of complex $\mathbf{C 6}$ is completed within one hour. Complex (2c) $\mathrm{AuCl}$ is more stable and the corresponding bis(NHC) complex $\mathbf{C 3}$ is formed within 20 hours. The bis(NHC) gold(I) complexes were identified by MALDI TOF MS, ${ }^{1} \mathrm{H}$ and ${ }^{13} \mathrm{C}\left\{{ }^{1} \mathrm{H}\right\}$ NMR spectroscopy. The NMR signals were identified unambiguously by adding samples of the independently prepared bis(NHC)s gold (I) complexes $\left[\left(\mathrm{C}_{3} \mathrm{H}_{4} \mathrm{~N}_{2}\right)_{2} \mathrm{Au}\right] \mathrm{Cl}^{28}$ (C6) and $\left[\left(\mathrm{C}_{4} \mathrm{H}_{6} \mathrm{~N}_{2}\right)_{2} \mathrm{Au}\right] \mathrm{Cl}^{29}$ (C3) to the corresponding reaction mixtures. Both bis(NHC) complexes $\mathbf{C 3}$ and $\mathbf{C 6}$ were tested for their catalytic activity and show no activity in the three component coupling reaction nor in the hydration of terminal alkynes.

The stability of imidazol-2-yl phosphane gold(I) complexes towards solvolysis depends on the number of hetero aryl substituents on the phosphorus atom. While the tris(imidazol-2-yl)phosphane complexes (1c) $\mathrm{AuCl}$ and (2c) $\mathrm{AuCl}$ decompose within minutes to the respective bis(NHC) gold(I) complexes, the corresponding BIP and MIP complexes are much more stable in protic solvents. This is in accord with the observed activity of the corresponding complexes in the three component coupling reaction under biphasic and homogenous conditions (Table 2 and 3). In contrast to the gold(I) complexes of imidazol-2-ylphosphane ligands, the isomeric compounds containing the $\mathrm{P}-\mathrm{C}$ bond in C4- or C5-position of the imidazolyl substituent are stable in protic solvents and do not decompose even after prolonged time.

Very recently, Chauvin et al. reported on the formation of NHC complexes from imidazolylphosphane complexes by $\mathrm{P}-\mathrm{C}$ bond cleavage. ${ }^{30}$ Here too, the reactivity of the imidazol-2ylphosphane ligands resembles the reactivity of imidazolylphosphanes after protonation of the imine $\mathrm{N}$ atom, (Scheme 7).

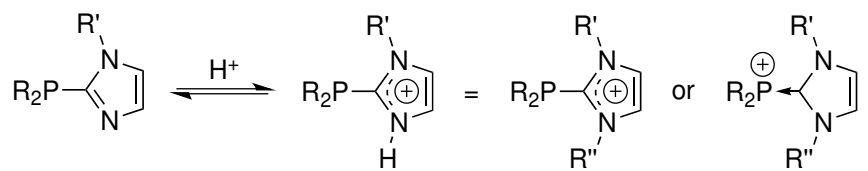

Scheme 7. Protonation of imidazol-2-phosphanes give imidazolylphosphanes. 


\section{Conclusion}

We have screened series of imidazole-based PN ligands in the gold(I) catalyzed three component coupling of aldehydes, amines and terminal alkynes as well as in the Markovnikov hydration of terminal alkynes. In homogenous solution the conversions to the respective propargylamine was considerably higher than under biphasic conditions. Complex [(2c)AuCl] shows the highest conversion of $95 \%$ with a catalyst loading of only $0.5 \mathrm{~mol} \%$. Under biphasic conditions a tenfold higher catalyst loading has to be used for high activity, which is due to decomposition of the gold(I) complexes to the corresponding bis(NHC) gold(I) complexes. Without any solvent the conversion rates using (2a) $\mathrm{AuCl}$ and $(\mathbf{2 b}) \mathrm{AuCl}$ are slightly higher (7\%). The conversion using (2c) $\mathrm{AuCl}$ is with $30 \%$ considerably higher. Based on the results we distinguished that connectivity of the imidazolyl substituents to the phosphorous atom, their substitution pattern as well as the number of heteroaromatic substituents have important effects on the catalytic activity of these gold(I) complexes.

In the Markovnikov hydration of 1-octyne the gold(I) complexes showed activities below or in the magnitude of $\left[\left(\mathrm{Ph}_{3} \mathrm{P}\right) \mathrm{AuCl}\right]$. Here the catalytic activity of complexes within the imidazol-4-yl phosphane series increases with increase in steric bulk of the substituent $(t-\mathrm{Bu}>\mathrm{Ph}>i$-Pr) at the C2-position, which has been reported for pyridyl-based PN ligands.

The imidazole-based PN ligands can display various coordination modes in their gold(I) complexes. Depending on the ligand-to-metal ratio polymetallic complexes with $\mathrm{Au}_{2}, \mathrm{Au}_{3}$ and $\mathrm{Au}_{4}$ units can be formed. A unique feature of imidazol-2-yl phosphanes within the isomeric imidazol-2$\mathrm{yl}, 4-\mathrm{yl}-$ and $-5 \mathrm{yl}$ phosphanes is their sensitivity towards $\mathrm{P}-\mathrm{C}$ bond cleavage in protic solvents. This reactivity resembles the NHC-phosphenium adduct nature of imidazol-2-yl phosphanes after protonation. In the corresponding gold(I) complexes this reaction results in the formation of catalytically inactive bis(NHC)-gold(I) complexes with imidazol-2-yl phosphane ligands as well as the formation of polynuclear species with imidazol-4(5)-yl phosphane ligands. 


\section{Experimental Section}

The procedures for the preparation of ligands 4- $\mathrm{MIP}^{\mathrm{Ph}}$ (4) and 4-MIP $\mathrm{M}^{t \mathrm{Bu}}$ (5) and complexes (L)AuCl, as well as the corresponding NMR and MS data and elemental analyses can be found in the supporting information. The compounds [(tht)AuCl], 1- methyl-2-trimethylsilylimidazole, 2$\left.\mathrm{MIP}^{\mathrm{H}}(\mathbf{1 a}), 2-\mathrm{TIP}^{\mathrm{H}}(\mathbf{1 c}),\right), 4-\mathrm{BIP}^{\mathrm{iPr}}(\mathbf{3 b}), 4-\mathrm{MIP}^{\mathrm{NMe}}(\mathbf{4}), 5-\mathrm{MIP}^{\mathrm{NMe}}$ (5) as well as the $\operatorname{gold}(\mathrm{I})$ complexes (2a)AuCl, $\quad(\mathbf{2 b}) \mathrm{AuCl}, \quad(\mathbf{2 c}) \mathrm{AuCl}, \quad[(\mathbf{3 a}) \mathrm{AuCl}], \quad\left[(\mathbf{3 c})_{2} \mathrm{Au}_{2}\right] \mathrm{Cl}_{2}, \quad \mathrm{Na}[(\mathrm{tppms}) \mathrm{AuCl}]$, $\mathrm{Na}_{2}\left[(\right.$ tppds)AuCl$]$ and $\mathrm{Na}_{3}[($ tppts $) \mathrm{AuCl}]$ were prepared according literature procedures. The preparations were carried out in Schlenk tubes under an atmosphere of dry nitrogen using anhydrous solvents purified according to standard procedures. The metal complexes were prepared using wet solvents. All chemicals were used as purchased. ${ }^{1} \mathrm{H}$ and ${ }^{31} \mathrm{P}\left\{{ }^{1} \mathrm{H}\right\}$ NMR spectra were recorded on a Bruker DRX 200 and ${ }^{13} \mathrm{C}\left\{{ }^{1} \mathrm{H}\right\}$ NMR spectra on a Bruker DRX 500 spectrometer. The ${ }^{1} \mathrm{H}$ and ${ }^{13} \mathrm{C}\left\{{ }^{1} \mathrm{H}\right\}$ NMR spectra were calibrated against the residual proton signals and the carbon signals of the solvents as internal references (chloroform- $d$ : $\delta_{\mathrm{H}}=7.30 \mathrm{ppm}$ and $\delta_{\mathrm{C}}=77.0 \mathrm{ppm}$; methanol- $d_{4}: \delta_{\mathrm{H}}$ $=3.31 \mathrm{ppm}$ and $\delta_{\mathrm{C}}=49.1 \mathrm{ppm}$, dmso- $d_{6}: \delta_{\mathrm{H}}=2.50 \mathrm{ppm}$ and $\left.\delta_{\mathrm{C}}=39.5 \mathrm{ppm} ; \mathrm{D}_{2} \mathrm{O}: \delta_{\mathrm{H}}=4.79\right)$ while the ${ }^{31} \mathrm{P}\left\{{ }^{1} \mathrm{H}\right\}$ NMR spectra were referenced to external $85 \% \mathrm{H}_{3} \mathrm{PO}_{4}$. The MALDI mass spectra were recorded on a Bruker Ultraflex MALDI-TOF mass spectrometer and ESI mass spectra with a Finnigan LCQ Deca Ion-Trap-API mass spectrometer. The elemental composition of the compounds was determined with a Perkin Elmer Analysator 2400 at the Institut für Pharmazeutische und Medizinische Chemie, Heinrich-Heine-Universita $\square \mathrm{t}$ Du $\square$ sseldorf.

Crystallographic data were collected at 183(2) K on an Oxford Diffraction Xcalibur system with a Ruby detector using Mo $\mathrm{K}_{\alpha}$ radiation $(\lambda=0.7107 \AA)$ that was graphite-monochromated. Suitable crystals were covered with oil (Infineum V8512, formerly known as Paratone N), mounted on top of a glass fibre and immediately transferred to the diffractometer. The program suite CrysAlis ${ }^{\text {Pro }}$ was used for data collection, multi-scan absorption correction and data reduction. ${ }^{31}$ Structures were solved with direct methods using SIR $97^{32}$ and were refined by full-matrix least-squares methods on $\mathrm{F}^{2}$ with SHELXL-97. ${ }^{33}$ The structures were checked for higher symmetry with help of the program Platon. ${ }^{34}$ The structure of $\left[(\mathbf{5})_{2} \mathrm{Au}_{3} \mathrm{Cl}_{2}\right] \mathrm{Cl}$ contained five chloroform molecules out of which three are 
half occupied. Two of these three chloroform molecules are sitting on special positions. Remaining residual electronic density caused by disordered solvent molecules was treated with the program utility SQUEEZE of the Platon program suite. ${ }^{34}$ Suitable restraints were applied. The cif files can be found in the supporting information. Additionally, CCDC 816459 and 816460 contain the supplementary crystallographic data for this paper. These data can be obtained free of charge from The Cambridge Crystallographic Data Centre via www.ccdc.cam.ac.uk/data_request/cif.

$\left[(\mathbf{5})_{2} \mathrm{Au}_{3} \mathrm{Cl}_{3}\right]$ : A dichloromethane solution $(10 \mathrm{~mL})$ of $4-\mathrm{MIP}^{t B u}(\mathbf{5})(77 \mathrm{mg}, 0.25 \mathrm{mmol})$ and [(tht)AuCl] $(120 \mathrm{mg}, 0.374 \mathrm{mmol})$ were stirred for $4 \mathrm{~h}$ at ambient temperature. The solution was concentrated in vacuo to $1 / 10^{\text {th }}$ and the product precipitated by addition of diethyl ether. Yield: 0.11 $\mathrm{g}(68 \%) .{ }^{1} \mathrm{H}$ NMR $\left(200 \mathrm{MHz}, 296 \mathrm{~K}, \mathrm{CDCl}_{3}\right): \delta=1.40\left(\mathrm{~s}, 18 \mathrm{H}, \mathrm{CH}_{3}\right), 6.83\left(\mathrm{~s}, 2 \mathrm{H}, H_{\mathrm{im}}\right), 7.62-7.73$ $\left(\mathrm{m}, 20 \mathrm{H}, H_{\mathrm{Ph}}\right), 13.52(\mathrm{br}, 2 \mathrm{H}, \mathrm{NH}) .{ }^{31} \mathrm{P}\left\{{ }^{1} \mathrm{H}\right\}-\mathrm{NMR}\left(81 \mathrm{MHz}, 296 \mathrm{~K}, \mathrm{CDCl}_{3}\right): \delta=18$ (s). MALDI TOF (DIT, $\left.\mathrm{CHCl}_{3}\right): m / z=541[\mathrm{LAuCl}]^{+}, 1277\left[\mathrm{~L}_{2} \mathrm{Au}_{3} \mathrm{Cl}_{2}\right]^{+} . \mathrm{C}_{38} \mathrm{H}_{42} \mathrm{~N}_{4} \mathrm{P}_{2} \mathrm{Au}_{3} \mathrm{Cl}_{3} \cdot 2 \mathrm{C}_{4} \mathrm{H}_{10} \mathrm{O}(1462.23)$ : calc. C 37.79, H 4.27, N 3.83; found C 37.8, H 4.2, N 3.8.

$\left[(\mathbf{3 c})_{2} \mathrm{Au}_{4} \mathrm{Cl}_{4}\right]$ : A dichloromethane solution $(10 \mathrm{~mL})$ of $4-\mathrm{TIP}^{i P r}(\mathbf{3 c})(70 \mathrm{mg}, 0.19 \mathrm{mmol})$ and [(tht) $\mathrm{AuCl}](128 \mathrm{mg}, 0.399 \mathrm{mmol})$ were stirred for $17 \mathrm{~h}$ at ambient temperature. All volatiles were removed in vacuo, the oily residue dissolved in dichloromethane $(2 \mathrm{~mL})$ and the product precipitated by addition of diethyl ether. Yield: $0.11 \mathrm{~g}(67 \%) .{ }^{1} \mathrm{H}$ NMR $\left(200 \mathrm{MHz}, 296 \mathrm{~K}, \mathrm{MeOD}-d_{4}\right): \delta=1.36-$ $1.50\left(\mathrm{~m}, 36 \mathrm{H}, \mathrm{CH}\left(\mathrm{CH}_{3}\right)_{2}\right), 3.15\left(\mathrm{sept},{ }^{3} J_{\mathrm{HH}}=6.85 \mathrm{~Hz}, 2 \mathrm{H}, \mathrm{CH}\left(\mathrm{CH}_{3}\right)_{2(\text { free })}\right), 3.66\left(\mathrm{sept},{ }^{3} J_{\mathrm{HH}}=7 \mathrm{~Hz}\right.$, 4H, $\mathrm{CH}\left(\mathrm{CH}_{3}\right)_{2 \text { (coord.) })}, 7.66$ (s, 2H, $\left.H_{\text {im(free })}\right), 7.72$ (s, 4H, $\left.H_{\text {im(coord. })}\right) .{ }^{31} \mathrm{P}\left\{{ }^{1} \mathrm{H}\right\} \mathrm{NMR}(81 \mathrm{MHz}, 296 \mathrm{~K}$, $\left.\mathrm{MeOD}-d_{4}\right): \delta=-14(\mathrm{~s}) \mathrm{ESI}^{+}\left(\mathrm{CH}_{3} \mathrm{OH}\right): m / z=556[\mathrm{LAu}]^{+}, 1110\left[\mathrm{~L}_{2} \mathrm{Au}_{2}-\mathrm{H}\right]^{+}, 1306\left[\mathrm{~L}_{2} \mathrm{Au}_{3}-2 \mathrm{H}\right]$. MALDI TOF (DIT, $\left.\mathrm{CHCl}_{3}\right): m / z=591[\mathrm{LAuCl}+\mathrm{H}]^{+}, 913\left[\mathrm{~L}_{2} \mathrm{Au}\right]^{+}, 11109\left[\mathrm{~L}_{2} \mathrm{Au}_{2}-\mathrm{H}\right]^{+}, 1305\left[\mathrm{~L}_{2} \mathrm{Au}_{3^{-}}\right.$ $2 \mathrm{H}]^{+} . \mathrm{C}_{36} \mathrm{H}_{54} \mathrm{~N}_{12} \mathrm{P}_{2} \mathrm{Au}_{4} \mathrm{Cl}_{2} \cdot 1 / 2 \mathrm{C}_{4} \mathrm{H}_{10} \mathrm{O}$ (1611.19): calc. C 28.30, H 3.69, $\mathrm{N}$ 10.42; found C 28.3, H 4.2, N 10.9.

Gold-Catalyzed Three-Component Coupling Reactions: In a Schlenk tube, under $\mathrm{N}_{2}$, the appropriate amount of the catalyst was weight and phenyl acetylene (160 $\mu \mathrm{L}, 1.60 \mathrm{mmol})$, benzaldehyde $(100 \mu \mathrm{L}, 1.00 \mathrm{mmol})$, and piperidine $(110 \mu \mathrm{L}, 1.10 \mathrm{mmol})$ were added. Without purification the reaction mixture was analyzed by ${ }^{1} \mathrm{H}$ NMR spectroscopy. 
Catalytic Hydration Reactions: Method a) Halide abstraction in situ: The gold complex (0.01 mmol, $5 \mathrm{~mol} \%$ catalyst loading) was dissolved in acetone $(0.4 \mathrm{~mL})$ and a solution of AgOTf (1 eq.) in acetone $(0.1 \mathrm{~mL})$ is added. A white precipitate formed and the solution turned yellow. Degassed 1-octyne $(30 \mu \mathrm{L})$ and water $(18 \mu \mathrm{L})$ were added and the reaction mixture stirred at $60{ }^{\circ} \mathrm{C}$ in an oil bath. The progress of the reaction was monitored via GC. Method b) The gold chlorido compound was dissolved in dichloromethane and a solution of $\operatorname{AgOTf}(1$ eq.) in dichloromethane was added. The mixture was stirred in a dark Schlenk tube at room temperature for $1 \mathrm{~h}$ and precipitated $\mathrm{AgCl}$ was filtered off. Removal of most of the solvent under vacuum and addition of diethyl ether resulted in the respective gold complex as a fine white powder, which was dried in vacuo. The so obtained gold compound (0.01 mmol, $5 \mathrm{~mol} \%$ catalyst loading) was dissolved in acetone $(0.4 \mathrm{~mL})$ and degassed 1-octyne $(30 \mu \mathrm{L})$ and water $(18 \mu \mathrm{L})$ were added to the solution. The reaction mixture was stirred at $60^{\circ} \mathrm{C}$ in an oil bath. The progress of the reaction was monitored via GC.

\section{References}

(1) (a) Gorin, D. J.; Toste, F. D. Nature 2007, 446, 395-403. (b) Hutchings, G. J. Catal. Today 2007, 122, 196-200. (c) Hashmi, A. S. K.; Hutchings, G. J. Angew. Chem., Int. Ed. Engl. 2006, 45,

7898-7936. (d) Hashmi, A. S. K. Angew. Chem., Int. Ed. Engl. 2005, 44, 6990-6993. (e) Dyker, G. Angew. Chem., Int. Ed. Engl. 2000, 39, 4237-4239.

(2) (a) Corma, A.; Juárez, R.; Boronat, M.; Sánchez, F.; Iglesias, M.; García, H. Chem. Commun. 2011, 47, 1446-1448. (b) Rudolph, M.; Hashmi, A. S. K. Chem. Commun. 2011, 47, 6536-6544. (c) Lu, P.: Boorman,T. C.; Slawin, A. M. Z.; Larrosa, I. J. Am. Chem. Soc. 2010, 132, 5580-5581. (d) Brenzovich, W. E.; Brazeau, J.-F.; Toste, F. D. Org. Lett. 2010, 12, 4728-4731. (e) Fürstner, A. Chem. Soc. Rev. 2009, 38, 3208-3221. (f) Hashmi, A. S. K.; Rudolph, M. Chem. Soc. Rev. 2008, 37, 1766-1775. (g) Hoffmann-Röder, A.; Krause, N. Org. Biomol. Chem. 2005, 3, 387-391.

(3) (a) Gorin, D. J.; Sherry, B. D.; Toste, F. D. Chem. Rev. 2008, 108, 3351-3378. (b) Li, Z.;

Brouwer, C.; He, C. Chem. Rev. 2008, 108, 3239-3265. (c) Arcadi, A. Chem. Rev. 2008, 108, 32663325. (d) Hashmi, A. S. K. Chem. Rev. 2007, 107, 3180-3211.

(4) Grotjahn, D. B. Top. Catal. 2010, 53, 1009-1014. 
(5) Grotjahn, D. B. Dalton Trans. 2008, 6497-6508.

(6) (a) Grotjahn, D. B.; Incarvito, C. D.; Rheingold, A. L. Angew. Chem., Int. Ed. Engl. 2001, 40, 3884-3887. (b) Grotjahn, D. B. Chem. Eur. J. 2005, 11, 7146-7153.

(7) Hashmi, A. S. K.; Schwarz, L.; Choi, J. H.; Frost, T. M. Angew. Chem., Int. Ed. Engl. 2000, $39,2285-2288$.

(8) Shi, F.; Deng, Y.; Yang, H.; Sima, T. Chem. Commun. 2001, 345-346.

(9) (a) Hayashi, T.; Sawamura, M.; Ito, Y. Tetrahedron 1992, 48, 1999-2012. (b) Hughes, P. F.; Smith, S. H.; Olson, J. T. J. Org. Chem. 1994, 59, 5799-5802.

(10) (a) Lein, M.; Rudolph, M.; Hashmi, A. S. K.; Schwerdtfeger, P. Organometallics 2010, 29, 2206-2210. (b) Hashmi, A. S. K.; Rudolph, M. Chem. Soc. Rev. 2008, 37, 1766-1775. (c) Sanz, S.; Jones, L. A.; Mohr, F.; Laguna, M. Organometallics 2007, 26, 952-957.

(11) (a) Yamamoto, Y.; Hayashi, H.; Saigoku, T.; Nishiyama, T. H. J. Am. Chem. Soc. 2005, 127, 10804-10805. (b) Jiang, B.; Xu, M. Angew. Chem. 2004, 116, 2597-2600.

(12) (a) Lo, V. K.-Y.; Liu, Y.; Wong, M.-K.; Che, C.-M. Org. Lett. 2006, 8, 1529-1532. (b) Wei, C.; Li, C.-J. J. Am. Chem. Soc. 2003, 125, 9584-9585.

(13) Li, P.; Zhang, Y.; Wang, L. Chem. Eur. J. 2009, 15, 2045-2049.

(14) Zhang, Y.; Li, P.; Wang, M.; Wang, L. J. Org. Chem. 2009, 74, 4364-4367.

(15) (a) Casado, R.; Contel, M.; Laguna, M.; Romero, P.; Sanz, S. J. Am. Chem. Soc. 2003, 125, 11925-11935. (b) Fukuda, Y.; Utimoto, K. J. Org. Chem. 1991, 56, 3729-3731. (c) Norman, R. O. C.; Parr, W. J. E.; Thomas, C. B. J. Chem. Soc. Perkin Trans. 1 1976, 1983-1987.

(16) Teles, S.; Brode, S.; Chabanas, M. Angew. Chem. Int. Ed. Engl. 1998, 37, 1414.

(17) (a) Hashmi, A. S. K.; Lothschuetz, C.; Graf, K.; Haeffner, T.; Schuster, A.; Rominger, F. Adv. Synth. Catal. 2011, 353, 1407-1412. (b) Hashmi, A. S. K.; Lothschuetz, C.; Boehling, C.; Hengst, 
T.; Hubbert, C.; Romiger, F. Adv. Synth. Catal. 2010, 352, 3001-3012. (c) Bartolom, C.; Ramiro, Z.; Garcia-Cuadrado, D.; Pérez-Galán, P.; Mihai Raducan, M.; Bour, C.; Echavarren A. M.; Espinet, P., Organometallics 2010, 29, 951-956. (d) Marion, N.; Nolan, S. P. Chem. Soc. Rev. 2008, 37, 17761782.

(18) (a) Czegeni, C. E.; Papp, G.; Katho, A.; Joo, F. J. Mol. Cat. A 2011, 340, 1-8. (b) Nun, P.; Ramon, R. S.; Gaillard, S.; Nolen, S. P. J. Organomet. Chem. 2011, 696, 7-11. (c) Allmassy, A.; Nagy, C. E.; Benyei, A. C.; Joo, F. Organometallics 2010, 29, 2484-2490. (d) Manon, N.; Ramon, R. S.; Nolan, S. P. J. Am. Chem. Soc. 2009, 131, 448-449.

(19) (a) Carriedo, G. A.; Lopez, S.; Suarez-Suarez, S.; Presa-Soto, D. Presa-Soto, A. J. Inorg. Chem. 2011, 1442-1447. (b) Mizushima, E.; Sato, K.; Hayashi, T.; Tanaka, M. Angew. Chem. Int. Ed. 2002, 41, 4563-4565.

(20) Khin, C., Hashmi, A. S. K., Rominger, F. Eur. J. Inorg. Chem., 2010, 1063.

(21) Bell, R. A.; Lock, C. J. L.; Scholten, C.; Valliant, J. F. Inorg. Chim. Acta. 1998, 274, 137142.

(22) (a) Kunz, P. C.; Süslüyan, D.; Beckmann, U. Phosphorus, Sulfur Silicon Relat. Elem. 2011, Manuscript ID: 547892. (b) Tolmachev, A. A.; Yurchenko, A. A.; Merculov, A. S.; Semenova, M. G.; Zarudnitskii, E. V.; Ivanov, V. V.; Pinchuk, A. M. Heteroat. Chem. 1999, 10, 585-597.

(23) (a). Kunz, P. C.; Huber, W.; Spingler, B. J. Chem. Crystallogr. 2011, 41, 105-110. (b) Kunz, P. C.; Kassack, M. U.; Hamacher, A.; Spingler, B. Dalton Trans. 2009, 7741-7747. (c) Kunz, P.C.; Kläui, W. Collect. Czech. Chem. Commun. 2007, 72, 492-502. (d) Kunz, P.C.; Reiß, G. J.; Frank, W.; Kläui, W. Eur. J. Inorg. Chem. 2003, 3945-3951.

(24) Kunz, P. C.; Kassack, M. U.; Hamacher, A.; Spingler, B. Dalton Trans. 2009, 7741-7747.

(25) Elie, B. T.; Levine, C.; Ubarretxena-Belandia, I.; Varela-Ramírez, A.; Aguilera, R. J.; Ovalle, R.; Contel, M. Eur. J. Inorg. Chem. 2009, 23, 3421-3430.

(26) Patil, N. T. ; Yamamoto, Y. ARKIVOC (Gainesville, FL, U. S.) 2007, 10, 121-141. 
(27) (a) Burini, A.; Galassi, R.; Ricci, S.; Bachechi, F.; Mohamed, A. A.; Fackler, J. P Inorg. Chem. 2010, 49, 513-518. (b) Monkowius, U.; Zabel, M.; Fleck, M.; Yersin, H. Z. Naturforsch. 2009, 64b, 1513-1524. (c) Bachechi, F.; Burini, A.; Galassi, R.; Pietroni, B.; Ricciutelli, M. Inorg. Chim. Acta 2004, 357, 4349-4357. (d) Catalano, V.; Horner, S. Inorg. Chem. 2003, 42, 8430-8438. (e) Bachechi, F.; Burini, A.; Fontani, M.; Galassi, R.; Macchioni, A.; Pietroni, B.; Zanello, P.; Zuccaccia, C. Inorg. Chim. Acta 2001, 323, 45-54. (f) Burini, A.; Galassi, R.; Pietroni, B.; Rafaiani, G. J. Organomet. Chem. 1996, 519, 161-167. (g) Burini, A.; Pietroni, B.; Galassi, R.; Valle, G.; Calogero, S. Inorg. Chim. Acta 1995, 229, 299-305.

(28) Kunz, P. C.; Wetzel, C.; Kögel, S.; Kassack, M. U.; Spingler, B. Dalton Trans. 2011, 40, 3537.

(29) Raubenheimer, H. G.; Lindeque, L.; Cronje, S. J. Organomet. Chem. 1996, 511, 177-184.

(30) Abdellah, I.; Lepetit, C.; Canac, Y.; Duhayon, C.; Chauvin, R. Chem. Eur. J. 2010, 16, 13095-13108.

(31) CrysAlisPro Software system. Oxford Diffraction Ltd, Oxford, UK, 2007, 171.32.

(32) Altomare, A.; Burla, M. C.; Camalli, M.; Cascarano, G. L.; Giacovazzo, C.;

Guagliardi, A.; Moliterni, A. G. G.; Polidori, G.; Spagna, R. J. Appl. Cryst. 1999, 32, 115-119.

(33) Sheldrick, G. M. Acta Cryst. 2008, A64, 112-122.

(34) Spek, A. J. Appl. Cryst. 2003, 36, 7-13. 


\section{Supporting Experimental Information}
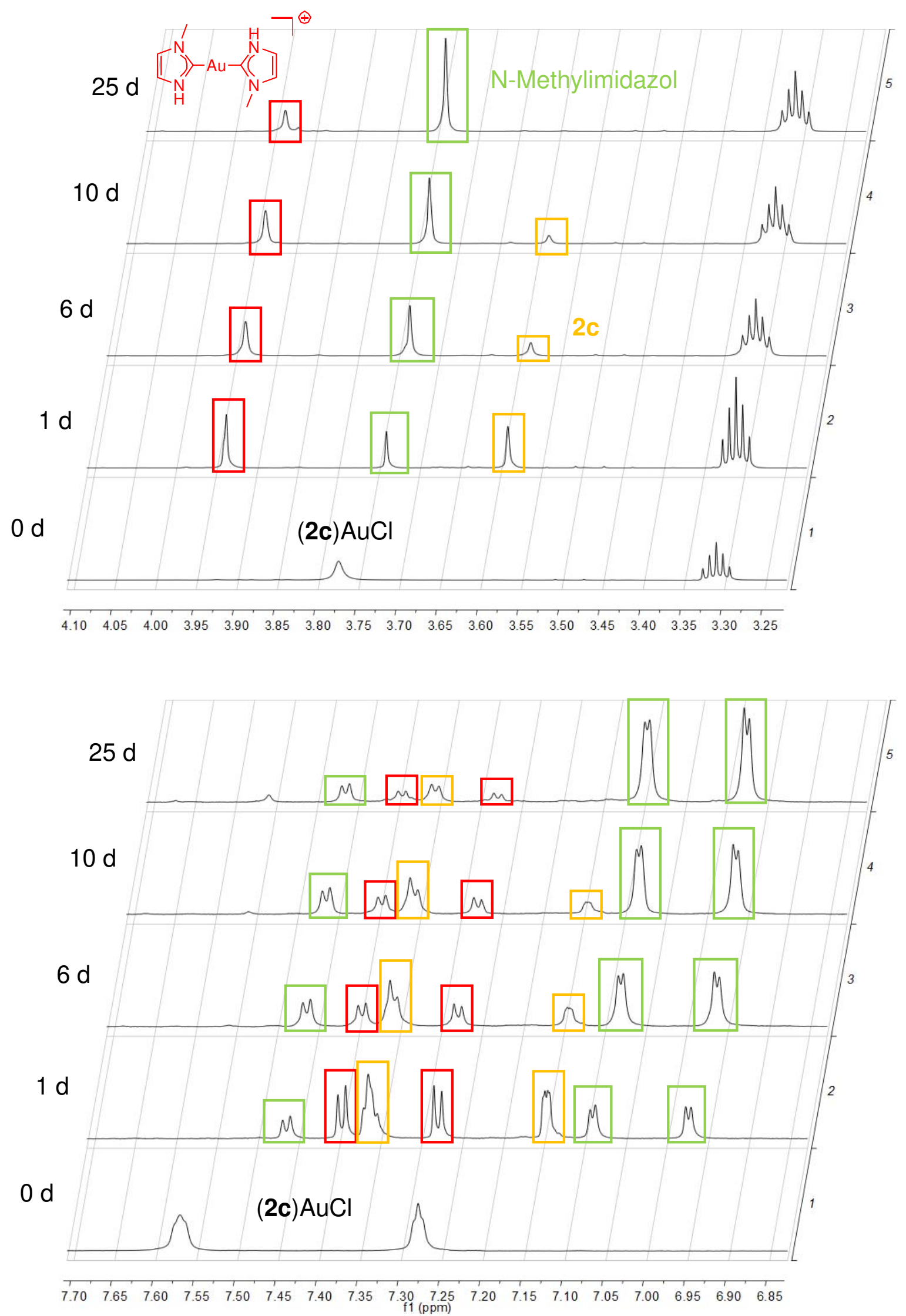

Figure ESI : NMR spectra of the decomposition of (2c) $\mathrm{AuCl}$ 
Table ESI1. Crystal data and structure refinement for $\left[(\mathbf{5})_{2} \mathrm{Au}_{3} \mathrm{Cl}_{2}\right] \mathrm{Cl} \cdot 3.5 \mathrm{CHCl}_{3}$ and $\left[(\mathbf{3 c})_{2} \mathrm{Au}_{4} \mathrm{Cl}_{2}\right] \mathrm{Cl}_{2}$.

\begin{tabular}{|c|c|c|}
\hline & {$\left[(\mathbf{5})_{2} \mathrm{Au}_{3} \mathrm{Cl}_{2}\right] \mathrm{Cl} \cdot 3.5 \mathrm{CHCl}_{3}$} & {$\left[(\mathbf{3 c})_{2} \mathrm{Au}_{4} \mathrm{Cl}_{2}\right] \mathrm{Cl}_{2}$} \\
\hline Empirical formula & $\mathrm{C}_{41.5} \mathrm{H}_{45.5} \mathrm{Au}_{3} \mathrm{Cl}_{13.5} \mathrm{~N}_{4} \mathrm{P}_{2}$ & $\mathrm{C}_{36} \mathrm{H}_{54} \mathrm{Au}_{4} \mathrm{Cl}_{4} \mathrm{~N}_{12} \mathrm{P}_{2}$ \\
\hline Formula weight & 1731.73 & 1646.52 \\
\hline Crystal system & Orthorhombic & Monoclinic \\
\hline Space group & Pnma & $\mathrm{P} 2{ }_{1} / \mathrm{n}$ \\
\hline $\mathrm{a}[\AA]$ & $21.7709(5)$ & $13.3045(3)$ \\
\hline $\mathrm{b}[\AA]$ & $52.9615(10)$ & $10.48360(17)$ \\
\hline $\mathrm{c}[\AA]$ & $10.8215(3)$ & $19.0693(3)$ \\
\hline$\beta\left[^{\circ}\right]$ & 90 & $101.1250(18)$ \\
\hline Volume $\left[\AA^{3}\right]$ & $12477.4(5)$ & $2609.79(8)$ \\
\hline Z & 8 & 2 \\
\hline Density (calculated) $\left[\mathrm{Mg} / \mathrm{m}^{3}\right]$ & 1.844 & 2.095 \\
\hline Absorption coefficient $\left[\mathrm{mm}^{-1}\right]$ & 7.698 & 11.512 \\
\hline Crystal size $\left[\mathrm{mm}^{3}\right]$ & $0.28 \times 0.10 \times 0.05$ & $0.18 \times 0.12 \times 0.03$ \\
\hline Crystal description & colourless plate & colourless plate \\
\hline Reflections collected & 45556 & 15143 \\
\hline Independent reflections & $15637[\mathrm{R}(\mathrm{int})=0.0426]$ & $6470[\mathrm{R}($ int $)=0.0330]$ \\
\hline Reflections observed & 9849 & 4685 \\
\hline Completeness to theta & $99.9 \%$ to $28.28^{\circ}$ & $99.9 \%$ to $28.28^{\circ}$ \\
\hline Data / restraints / parameters & $15637 / 10 / 624$ & $6470 / 61 / 275$ \\
\hline Goodness-of-fit on $\mathrm{F}^{2}$ & 0.933 & 1.001 \\
\hline Final $\mathrm{R}$ indices $[\mathrm{I}>2 \operatorname{sigma}(\mathrm{I})]$ & $\mathrm{R} 1=0.0416, \mathrm{wR} 2=0.1005$ & $\mathrm{R} 1=0.0399, \mathrm{wR} 2=0.0914$ \\
\hline $\mathrm{R}$ indices (all data) & $\mathrm{R} 1=0.0785, \mathrm{wR} 2=0.1064$ & $\mathrm{R} 1=0.0638, \mathrm{wR} 2=0.0962$ \\
\hline Largest diff. peak and hole $\left[\mathrm{e} . \AA^{-3}\right]$ & 1.253 and -1.585 & 2.491 and -1.096 \\
\hline
\end{tabular}


Bisimidazol-2-ylphenyl phosphane, $\left(2-B I P^{H}, \mathbf{1 b}\right)$ : A solution of n-butyl lithium in $n$-hexane $(1.6 \mathrm{M}$, $12 \mathrm{~mL}, 19 \mathrm{mmol})$ was added drop-wise to a solution of $3.0 \mathrm{~g}(18 \mathrm{mmol})$ of 1diethoxymethylimidazole in diethyl ether $(150 \mathrm{~mL})$ at $-78^{\circ} \mathrm{C}$. The reaction mixture was stirred at $40^{\circ} \mathrm{C}$ for $1 \mathrm{~h}$ and then was cooled to $-78^{\circ} \mathrm{C}$ and $\mathrm{PCl}_{3}(1.56 \mathrm{~g}, 8.72 \mathrm{mmol})$ was added. The reaction mixture was stirred at $-78^{\circ} \mathrm{C}$ for $1 \mathrm{~h}$ and at ambient temperature over night. Concentrated ammonia solution $(5 \mathrm{~mL})$ was added, the phases separated, the organic phase was collected and all volatiles were removed in vacuo. The oily residue was dissolved in $100 \mathrm{~mL}$ acetone/water (10:1) and stirred at ambient temperature for $72 \mathrm{~h}$. The resulting precipitate was collected by filtration and dried in vacuo. Yield: $1.1 \mathrm{~g}(52 \%) .{ }^{1} \mathrm{H}$ NMR $\left(\mathrm{MeOD}-d_{4}\right): \delta=7.27-7.35(\mathrm{~m}, 9 \mathrm{H}) .{ }^{31} \mathrm{P}\left\{{ }^{1} \mathrm{H}\right\} \mathrm{NMR}$ (MeOD$\left.d_{4}\right): \delta=-46(\mathrm{~s}) \cdot \mathrm{ESI}^{+}\left(\mathrm{CH}_{3} \mathrm{OH}\right): m / z(\%)=243[\mathrm{~L}]^{+} \cdot \mathrm{C}_{12} \mathrm{H}_{11} \mathrm{~N}_{4} \mathrm{P} \cdot \mathrm{CH}_{3} \mathrm{OH}(274.26)$ : calc. C 56.93, $\mathrm{H}$ 5.51, N 20.43; found C 56.4, H 5.6, N 20.7.

2-Phenylimidazol-4(5)-yldiphenyl phosphane (4-MIP $\left.{ }^{P h}, 4\right)$ : 1-Methoxymethyl-2-phenylimidazole $(1.5 \mathrm{~g}, 8.0 \mathrm{mmol})$ is placed in a Schlenk tube equipped with a magnetic stirring bar and dissolved in dry thf $(100 \mathrm{~mL})$. At $-78{ }^{\circ} \mathrm{C}$ tert-butyllithium $(5.3 \mathrm{~mL}, 1.6 \mathrm{M}$ in hexane $)$ is added slowly to the solution, which turns deep red. The reaction mixture is stirred at $-78{ }^{\circ} \mathrm{C}$ for $1 \mathrm{~h}$ until the diphenylchlorophosphane $(1.6 \mathrm{~mL}, 8.0 \mathrm{mmol})$ is slowly added to the solution, which turns yellow and is then stirred over night at room temperature. The solvent is removed and the residue is dissolved in with ammonia-saturated dichloromethane. This solution is stirred over night and the white solid is filtered off. The solvent is removed from the filtrate and the residue dissolved in acetone/water $(10: 1)$ and $2 \mathrm{~mL}$ of conc. Hydrochloric acid added. The mixture is refluxed for 4 hours, all volatiles removed in vacuo and the residue dissolved in a minimum amount of ethanol and sodium hydroxide solution added. The precipitate is filtered off, washed with diethyl ether and dried in vacuo. Yield: $1.39 \mathrm{~g}(53 \%) .{ }^{1} \mathrm{H}$ NMR $\left(200 \mathrm{MHz}, \mathrm{CDCl}_{3}\right): \delta=3.23\left(\mathrm{~s}, 3 \mathrm{H}, \mathrm{OCH}_{3}\right), 5.40(\mathrm{~d}, J=$ $\left.1.5 \mathrm{~Hz}, \mathrm{CH}_{2}\right), 6.86 \mathrm{~Hz}\left(\mathrm{~s}, \mathrm{H}_{\mathrm{im}}\right), 7.33-7.85$ (m, 15H, Ph). ${ }^{31} \mathrm{P}\left\{{ }^{1} \mathrm{H}\right\} \mathrm{NMR}\left(81 \mathrm{MHz}, \mathrm{CDCl}_{3}\right): \delta=-34.0$. ESI MS (methanol): $m / z$ (rel. int.) $=386(100)[\mathrm{M}+\mathrm{NaCl}]^{+}, 329(15)[\mathrm{M}+\mathrm{H}]^{+} \cdot \mathrm{C}_{21} \mathrm{H}_{17} \mathrm{~N}_{2} \mathrm{P} \cdot \mathrm{C}_{2} \mathrm{H}_{5} \mathrm{OH}$ (374.42): calc. C 73.78, H, 6.19, N 7.48; found C 73.85, H 5.50, N 7.02. 
2-tert-Butylimidazol-4(5)-yldiphenyl phosphane (4-MIP $\left.P^{t B u}, \quad 5\right)$ : 1-Methoxymethyl-2-tertbutylimidazole $(1.3 \mathrm{~g}, 8.0 \mathrm{mmol})$ is placed in a Schlenk tube equipped with a magnetic stirring bar and dissolved in dry thf $(100 \mathrm{~mL})$. At $-78{ }^{\circ} \mathrm{C}$ tert-butyllithium $(5.3 \mathrm{~mL}, 1.6 \mathrm{M}$ in hexane $)$ is added slowly to the solution, which turns deep red. The reaction mixture is stirred at $-78{ }^{\circ} \mathrm{C}$ for $1 \mathrm{~h}$ until the diphenylchlorophosphane $(1.6 \mathrm{~mL}, 8.0 \mathrm{mmol})$ is slowly added to the solution, which turns yellow and is then stirred over night at room temperature. The solvent is removed and the residue is dissolved in with ammonia-saturated dichloromethane. This solution is stirred over night and the white solid is filtered off. The solvent is removed from the filtrate and the residue dissolved in acetone/water $(10: 1)$ and $2 \mathrm{~mL}$ of conc. hydrochloric acid added. The mixture is refluxed for 4 hours, all volatiles removed in vacuo and the residue dissolved in a minimum amount of ethanol and sodium hydroxide solution added. The precipitate is filtered off, washed with diethyl ether and dried in vacuo. Yield: $1.06 \mathrm{~g}(43 \%) .{ }^{1} \mathrm{H}$ NMR $\left(200 \mathrm{MHz} \mathrm{CDCl}_{3}\right): \delta=1.34\left(\mathrm{~s}, 9 \mathrm{H}, \mathrm{CH}_{3}\right), 6.91 \mathrm{~Hz}\left(\mathrm{~s}, \mathrm{H}_{\mathrm{im}}\right)$, 7.25-7.35 (m, 10H, Ph). ${ }^{31} \mathrm{P}\left\{{ }^{1} \mathrm{H}\right\} \operatorname{NMR}\left(81 \mathrm{MHz}, \mathrm{CDCl}_{3}\right): \delta=-31.0 . \mathrm{ESI}^{+}$(methanol): $\mathrm{m} / z(\%)=$ $309[\mathrm{M}+\mathrm{H}]^{+}$(100), $249[\mathrm{M}-t \mathrm{Bu}]^{+}(95) . \mathrm{C}_{19} \mathrm{H}_{21} \mathrm{~N}_{2} \mathrm{P} \cdot 5 / 3 \mathrm{H}_{2} \mathrm{O}$ (308.36): calc. C 67.44, H, 7.23, N 8.27; found C 67.49, H 6.90, N 8.14.

General procedure for the synthesis of gold(I) complexes (L)AuCl: To a stirred solution of (tht) $\mathrm{AuCl}$ was added the ligand solution in a convenient solvent. The reaction solution was stirred for at least $4 \mathrm{~h}$ at room temperature. The resulting solution was concentrated in vacuo and diethyl ether was layered to precipitate white powders. The product precipitate was filtered and dried in vacuo.

$\left(2-\mathrm{MIP}{ }^{H}\right) \mathrm{AuCl}$, (1a) $\mathrm{AuCl}$ : A solution of (tht) $\mathrm{AuCl}(80 \mathrm{mg}, 0.25 \mathrm{mmol})$ in $\mathrm{CH}_{2} \mathrm{Cl}_{2}(5 \mathrm{~mL})$ was added to a stirred solution of 2-MIP ${ }^{\mathrm{H}}(63 \mathrm{mg}, 0.25 \mathrm{mmol})$ in $\mathrm{CH}_{3} \mathrm{OH}(5 \mathrm{~mL})$. Yield: $98 \mathrm{mg}(81 \%)$. ${ }^{1} \mathrm{H}$ NMR $\left(\mathrm{MeOD}-d_{4}\right): \delta=7.51-7.66\left(\mathrm{~m}, 12 \mathrm{H}, H_{\mathrm{Ph} / \mathrm{im}}\right) .{ }^{31} \mathrm{P}\left\{{ }^{1} \mathrm{H}\right\} \mathrm{NMR}\left(\mathrm{MeOD}-d_{4}\right): \delta=16(\mathrm{~s}) . \mathrm{ESI}^{+}$ $\left(\mathrm{CH}_{3} \mathrm{OH}\right): m / z(\%)=898\left[(\mathrm{LAuCl})_{2}\right]^{+} . \mathrm{MALDI} \mathrm{MS}\left(\mathrm{CH}_{3} \mathrm{OH}\right): m / z(\%)=485[\mathrm{LAuCl}]^{+}, 897$ $\left[(\mathrm{LAuCl})_{2}\right]^{+} . \quad \mathrm{EI} \quad \mathrm{MS}\left(\mathrm{Pt}, 180^{\circ} \mathrm{C}\right): m / z \quad(\%)=251[\mathrm{~L}]^{+}, 484[\mathrm{LAu}]^{+}, 895\left[\mathrm{~L}_{2} \mathrm{Au}_{2}-2 \mathrm{H}\right]^{+}$. $\mathrm{C}_{15} \mathrm{H}_{13} \mathrm{~N}_{2} \mathrm{PAuCl} \cdot 1 / 2 \mathrm{CH}_{2} \mathrm{Cl}_{2}$ (527.14): calc. C 35.32, H 2.68, N 5.31; found C 35.4, H 2.4, N 5.1. 
$\left(2-B I P^{H}\right) A u C l$, (lb) $\mathrm{AuCl}$ : A solution of (tht) $\mathrm{AuCl}(100 \mathrm{mg}, 0.31 \mathrm{mmol})$ in $\mathrm{CH}_{2} \mathrm{Cl}_{2}(5 \mathrm{~mL})$ was added to a stirred solution of $2-\mathrm{BIP}^{\mathrm{H}}(76 \mathrm{mg}, 0.31 \mathrm{mmol})$ in $\mathrm{CH}_{3} \mathrm{OH}(10 \mathrm{~mL})$. Yield: $0.11 \mathrm{~g}(74 \%)$. ${ }^{1} \mathrm{H}$ NMR $\left(\mathrm{MeOD}-d_{4}\right): \delta=7.51-7.73\left(\mathrm{~m}, 9 \mathrm{H}, H_{\mathrm{im} / \mathrm{Ph}}\right) .{ }^{31} \mathrm{P}\left\{{ }^{1} \mathrm{H}\right\}$ NMR $\left(\mathrm{MeOD}-d_{4}\right): \delta=-4(\mathrm{~s}) . \mathrm{ESI}^{+}$ $\left(\mathrm{CH}_{3} \mathrm{OH}\right): m / z(\%)=475[\mathrm{LAuCl}]^{+}, 877\left[(\mathrm{LAu})_{2}\right]^{+}$. MALDI MS $\left(\mathrm{CH}_{3} \mathrm{OH}\right): m / z(\%)=440[\mathrm{LAu}]^{+}$, 878[(LAu $\left.)_{2}\right]^{+} . \mathrm{C}_{12} \mathrm{H}_{11} \mathrm{~N}_{4} \mathrm{PAuCl} \cdot 1 / 4 \mathrm{CH}_{2} \mathrm{Cl}_{2}$ (495.87): calc. C 29.67, $\mathrm{H} 2.34, \mathrm{~N} 11.30$; found $\mathrm{C} \mathrm{30.1,} \mathrm{H}$ 2.7, N 10.9.

$\left(2-T I P^{H}\right) A u C l,(1 c) A u C l$ : A solution of (tht) $\mathrm{AuCl}(61 \mathrm{mg}, 0.19 \mathrm{mmol})$ in $\mathrm{CH}_{2} \mathrm{Cl}_{2}(5 \mathrm{~mL})$ was added to a stirred suspension of $2-\mathrm{TIP}^{\mathrm{H}}(44 \mathrm{mg}, 0.19 \mathrm{mmol})$ in acetone $(15 \mathrm{~mL})$. The mixture was stirred for $72 \mathrm{~h}$ and the resulting precipitate was filtered, washed with diethylether and dried under vacuo. Yield : $64 \mathrm{mg}(73 \%) .{ }^{1} \mathrm{H}$ NMR (dmso-d $): \delta=7.41\left(\mathrm{~s}, 6 \mathrm{H}, H_{\mathrm{im}}\right), 13.24$ (br, NH). ${ }^{31} \mathrm{P}\left\{{ }^{1} \mathrm{H}\right\} \mathrm{NMR}$ $\left(\mathrm{dmso}-d_{6}\right): \delta=-20(\mathrm{~s})$. MALDI MS $\left(\mathrm{CH}_{3} \mathrm{OH}\right): m / z(\%)=333\left[\left(\mathrm{C}_{3} \mathrm{H}_{4} \mathrm{~N}_{2}\right) \mathrm{Au}\right]^{+}, 465[\mathrm{LAuCl}]^{+}$. $\mathrm{C}_{9} \mathrm{H}_{9} \mathrm{~N}_{6} \mathrm{PAuCl} \cdot 1 / 2 \mathrm{CH}_{2} \mathrm{Cl}_{2}$ (507.07): calc. C 22.50, H 1.99, N 16.57; found C 22.1, H 1.8, N 16.3.

(4-BIP $\left.{ }^{i P r}\right) \mathrm{AuCl},(3 \boldsymbol{b}) \mathrm{AuCl}$ : A solution of (tht) $\mathrm{AuCl}(60 \mathrm{mg}, 0.19 \mathrm{mmol})$ in $\mathrm{CH}_{2} \mathrm{Cl}_{2}(5 \mathrm{~mL})$ was added to a stirred solution of 4-BIP ${ }^{i P r}(61 \mathrm{mg}, 0.19 \mathrm{mmol})$ in $\mathrm{CH}_{3} \mathrm{OH}(5 \mathrm{~mL})$. Yield: $93 \mathrm{mg}(88 \%)$. ${ }^{1} \mathrm{H}$ NMR $\left(\mathrm{MeOD}-d_{4}\right): \delta=1.37\left(\mathrm{~d}, J=6.89 \mathrm{~Hz}, 12 \mathrm{H}, \mathrm{CH}\left(\mathrm{CH}_{3}\right)_{2}\right), 3.18-3.28\left(\mathrm{sept}, 2 \mathrm{H}, H_{2}\right), 7.52-$ $7.80\left(\mathrm{~m}, 7 \mathrm{H}, H_{\mathrm{Ph} / \mathrm{im}}\right) .{ }^{31} \mathrm{P}\left\{{ }^{1} \mathrm{H}\right\} \mathrm{NMR}\left(\mathrm{MeOD}-d_{4}\right): \delta=-5$ (br). $\mathrm{ESI}^{+}\left(\mathrm{CH}_{3} \mathrm{OH}\right): m / z(\%)=524[\mathrm{LAu}]^{+}$, $1046\left[(\mathrm{LAu})_{2}\right]^{+}$. MALDI MS $\left(\mathrm{CH}_{3} \mathrm{OH}\right): m / z(\%)=559[\mathrm{LAuCl}]^{+}, 1045\left[(\mathrm{LAu})_{2}\right]^{+}, 1081\left[(\mathrm{LAu})_{2} \mathrm{Cl}\right]^{+}$. $\mathrm{C}_{18} \mathrm{H}_{23} \mathrm{~N}_{4} \mathrm{PAuCl}$ (558.80): calc. C: $38.69, \mathrm{H} 4.15, \mathrm{~N}$ 10.03; found C: 38.9, H 3.9, N 10.3.

(4-MIP $\left.{ }^{N M e}\right) \mathrm{AuCl}$, (6) $\mathrm{AuCl}$ : A solution of (tht) $\mathrm{AuCl}(96 \mathrm{mg}, 0.3 \mathrm{mmol})$ in $\mathrm{CH}_{2} \mathrm{Cl}_{2}(5 \mathrm{~mL})$ was added to a stirred solution of 4-MIP ${ }^{\mathrm{NMe}}(80 \mathrm{mg}, 0.3 \mathrm{mmol})$ in $\mathrm{CH}_{2} \mathrm{Cl}_{2}(5 \mathrm{~mL})$. Yield: $99 \mathrm{mg}(66 \%)$. ${ }^{1} \mathrm{H}$ NMR $\left(\mathrm{CDCl}_{3}\right): \delta=3.73\left(\mathrm{~s}, 3 \mathrm{H}, \mathrm{NCH}_{3}\right), 7.35-7,78\left(\mathrm{~m}, 7 \mathrm{H}, H_{\mathrm{Ph} / \mathrm{im}}\right) .{ }^{31} \mathrm{P}\left\{{ }^{1} \mathrm{H}\right\} \mathrm{NMR}\left(\mathrm{CDCl}_{3}\right): \delta=$ 11 (s). MALDI MS $\left(\mathrm{CH}_{3} \mathrm{OH}\right): m / z(\%)=463[\mathrm{LAu}]^{+}, 499[\mathrm{LAuCl}], 729\left[\mathrm{~L}_{2} \mathrm{Au}\right]^{+}, 961\left[\mathrm{~L}_{2} \mathrm{Au}_{2} \mathrm{Cl}\right]^{+}$, $1193\left[\mathrm{~L}_{2} \mathrm{Au}_{3} \mathrm{Cl}_{2}\right]^{+} . \mathrm{C}_{16} \mathrm{H}_{15} \mathrm{~N}_{2} \mathrm{PAuCl} \cdot 1 / 2 \mathrm{CH}_{2} \mathrm{Cl}_{2} \cdot 1 / 4 \mathrm{C}_{4} \mathrm{H}_{10} \mathrm{O}$ (559.70): calc. C 37.55, H 3.33, N 5.01; found C 37.6, H 3.2, N 4.6.

(5-MIP $\left.{ }^{N M e}\right) \mathrm{AuCl}$, (7) $\mathrm{AuCl}$ : A solution of (tht) $\mathrm{AuCl}(100 \mathrm{mg}, 0.31 \mathrm{mmol})$ in $\mathrm{CH}_{2} \mathrm{Cl}_{2}(5 \mathrm{~mL})$ was added to a stirred solution of 5-MIP ${ }^{\mathrm{NMe}}(83 \mathrm{mg}, 0.31 \mathrm{mmol})$ in $\mathrm{CH}_{2} \mathrm{Cl}_{2}(5 \mathrm{~mL})$. Yield: $90 \mathrm{mg}(58 \%)$. ${ }^{1} \mathrm{H}$ NMR $\left(\mathrm{CDCl}_{3}\right): \delta=3.81\left(\mathrm{~s}, 3 \mathrm{H}, \mathrm{NCH}_{3}\right), 6.73\left(\mathrm{br}, 1 \mathrm{H}, H_{\mathrm{im}}\right), 7.55-7.73\left(\mathrm{~m}, 10 \mathrm{H}, H_{\mathrm{ph}}\right), 7.79(\mathrm{~s}$, 
$\left.1 \mathrm{H}, H_{\mathrm{im}}\right) .{ }^{31} \mathrm{P}\left\{{ }^{1} \mathrm{H}\right\}$ NMR $\left(\mathrm{dmso}-d_{6}\right): \delta=11(\mathrm{~s})$. MALDI MS $\left(\mathrm{CH}_{3} \mathrm{OH}\right): m / z(\%)=499[\mathrm{LAuCl}]^{+}$. $\mathrm{C}_{16} \mathrm{H}_{15} \mathrm{~N}_{2} \mathrm{PAuCl} \cdot 1.5 \mathrm{CHCl}_{3} \cdot 1 \mathrm{H}_{2} \mathrm{O}$ (695.77): calc. C 30.21, H 2.68, N 4.03; found C 29.8, H 2.8, N 4.4 .

(4-MIP $\left.P^{P h}\right) \mathrm{AuCl}$, (4) $\mathrm{AuCl}$ : A solution of (tht) $\mathrm{AuCl}(20 \mathrm{mg}, 0.062 \mathrm{mmol})$ in $\mathrm{CH}_{2} \mathrm{Cl}_{2}(2 \mathrm{~mL})$ was added to a stirred solution of 4-MIP ${ }^{\mathrm{Ph}}(20 \mathrm{mg}, 0.062 \mathrm{mmol})$ in $\mathrm{CH}_{2} \mathrm{Cl}_{2}(2 \mathrm{~mL})$. Yield: $32 \mathrm{mg}(93 \%)$. ${ }^{1} \mathrm{H}$ NMR $\left(\mathrm{dmso}-d_{6}\right): \delta=7.43-8.14(\mathrm{~m}, 16 \mathrm{H}, \mathrm{Ph}+\mathrm{CH}) ;{ }^{31} \mathrm{P}\left\{{ }^{1} \mathrm{H}\right\}-\mathrm{NMR}\left(\mathrm{dmso}-d_{6}\right): \delta=11$ (s). MALDI MS $\left(\mathrm{CH}_{3} \mathrm{OH}\right): m / z=1317 \quad\left[\mathrm{Au}_{3} \mathrm{~L}_{2} \mathrm{Cl}_{2}\right]^{+}, 1085\left[\mathrm{Au}_{2} \mathrm{~L}_{2} \mathrm{Cl}\right]^{+}, 560 \quad[\mathrm{AuLCl}]^{+}, 524 \quad[\mathrm{AuL}]^{+}$. $\mathrm{C}_{21} \mathrm{H}_{17} \mathrm{~N}_{2} \mathrm{P}_{1} \mathrm{AuCl}$ (560.77): calc. C 41.92, H 2.97, N 4.33; found C 41.90, H 3.27, N 3.95.

(4-MIP $\left.{ }^{t B u}\right) \mathrm{AuCl}$, (5) $\mathrm{AuCl}$ : A solution of (tht) $\mathrm{AuCl}(20 \mathrm{mg}, 0.062 \mathrm{mmol})$ in $\mathrm{CH}_{2} \mathrm{Cl}_{2}(2 \mathrm{~mL})$ was added to a stirred solution of 4-MIP ${ }^{\mathrm{Ph}}(19 \mathrm{mg}, 0.062 \mathrm{mmol})$ in $\mathrm{CH}_{2} \mathrm{Cl}_{2}(2 \mathrm{~mL})$. Yield: $28 \mathrm{mg}(89 \%)$. ${ }^{1} \mathrm{H}$ NMR $\left(\mathrm{dmso}-d_{6}\right): \delta=1.32\left(\mathrm{~s}, 9 \mathrm{H}, \mathrm{CH}_{3}\right), 7.56-7.75(\mathrm{~m}, 11 \mathrm{H}, \mathrm{Ph}+\mathrm{CH}), 12.58(\mathrm{bs}, 1 \mathrm{H}, \mathrm{NH})$. ${ }^{31} \mathrm{P}\left\{{ }^{1} \mathrm{H}\right\}$ NMR $\left(\right.$ dmso- $\left.d_{6}\right): \delta=11$ (s). MALDI MS $\left(\mathrm{CH}_{3} \mathrm{OH}\right): m / z=1277\left[\mathrm{Au}_{3} \mathrm{~L}_{2} \mathrm{Cl}_{2}\right]^{+}, 1241$ $\left[\mathrm{Au}_{3} \mathrm{~L}_{2} \mathrm{Cl}\right]^{+}, 540[\mathrm{AuLCl}]^{+} . \mathrm{C}_{19} \mathrm{H}_{21} \mathrm{~N}_{2} \mathrm{PAuCl} \cdot 1.5 \mathrm{CH}_{2} \mathrm{Cl}_{2}$ (668.18): calc. C $36.85 \% ; \mathrm{H} 3.62 \%$; N 4.19 $\%$; found C $36.7 \%$ H $3.7 \%$ N $3.7 \%$. 